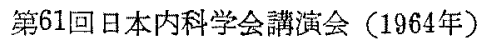 \\ 筫血症ことに巨赤芽球性貧血について
}

\author{
京都大学医学部内科第一講座 \\ 教 授 脇 坂 行一

\section{STUDIES ON ANEMIA WITH SPECIAL REFERENCE TO MEGALOBLASTIC ANEMIA} \\ Gyoichi WAKISAKA \\ The First Division, Department of Internal Medicine, \\ Faculty of Medicine, Kyoto University
}

\section{I. 緒 言}

各種貧血症の病態生理および発生機序に関する 研究は近年生化学, 免疫血液学の進歩, 放射性同 位元䋈の応用などによつて，著しい発展を逐げ たが、こ〉では各種㥽血のうち主としてビタミン

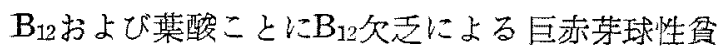
血をとり上げ，その病態生理，登生機序について 報告する。

II. わが国における悪性䝯血および類似の巨 赤芽球性負血の統計的観察

わが国において，悪性筫血が初的て報告せられ たのは，1903年(明治36年)であるが，その後1963 年までにわが国で報告せられた瑟性貧血および類 似の巨赤芽球性貧血は 492例である122)（表 1 ).

その年次的消長をみると最初の25年間は報告が 栖めて少なく，1 年平均約 1 例に過ぎないが, 1928

表 1 . Number of cases of megaloblastic anemias reported in Japan (1904-1963)

\begin{tabular}{|c|c|c|c|c|c|c|c|c|c|c|c|c|c|c|c|c|}
\hline & & -05 & & & & & of & $\begin{array}{l}48 \\
-411 \\
-11\end{array}$ & & & 13 & -14 & -15 & -16 & -17 & 88 \\
\hline Number & 0 & 1 & 1 & 1 & 0 & 1 & 1 & 2 & & 2 & 1 & 1 & 1 & & 10 & 1 \\
\hline yoar & Fig & 20 & -21 & 22 & -23 & -24 & $4-2$ & $5 \sqrt{17}$ & & 27 & 28 & -29 & -3 & -3 & $\mid-32$ & -33 \\
\hline Number? & 0 & 3 & 0 & 0 & 4 & 1 & 2 & 0 & & 0 & 11 & $\theta$ & 12 & 6 & 11 & 14 \\
\hline Year & -34 & 35 & 36 & 37 & 36 & 33 & -4 & -4 & & 12 - & 43 & & 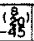 & 46 & -47 & $-4 \theta$ \\
\hline Numiter & 12 & 6 & 8 & 7 & I & 17 & 15 & 13 & & 5 & 33 & 1 & 0 & 0 & 2 & 9 \\
\hline Yoor & -49 & 50 & 51 & & & & & & & & & & & & & -63 \\
\hline Number & & $\theta$ & 41 & 42 & & & & & & & 10 & & & $\begin{array}{l}15 \\
(14)\end{array}$ & (6) & 5 \\
\hline
\end{tabular}

年以後抢よび1951年以後には, 報告功著しく增加 している、これはそれぞれMinot, Murphy3)によ る䀒缄食療法の発見および 葉酸 $\mathrm{B}_{12}$ の発見に刺邀 せられ，注意が喚起せられた〉めであろう。以上 の統計が示すように，わが国においても悪性貧血 および類似の巨赤芽球性賀血はよく注意方れば以 前考えられていた忹ど稀な疾患ではないことがわ かる，わが国に打方巨赤芽球顀血の原因として 洁覀性貧血（いわゆるAddison氏，あるいはBiermer氏貧血）が 408 例 (82.9\%) で最主多い.以 下單に悪性筫血という場合はこの種のものを指す こと〉する．次いで奼娠によるもの66例（13.4 $\%)$, 胃切除後のもの14例 $(2.8 \%)$, 広節裂頭条虫 の寄生によるもの3例( $0.6 \%$ ), 胃癌に合併せる 801 例 $(0.3 \%)$ 上なつている.

III. 消化管よりのB 12 の吸収

悪性貧血の成因については今日一般に胃液中に

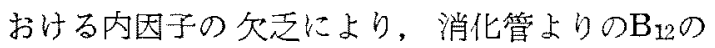

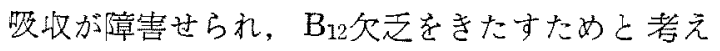
られている，消化管よりのB 12 の吸収㧍よびこれ に及ほす内因子その活物質の影響を研究する 上に大きな進歩をもたらしたものは放射性 $\mathrm{B}_{12}$ の 応用である4 (5)6)。

1) 正常例

われわれの成績7によると正常例 9 例に ${ }^{60} \mathrm{Co}$ $\mathrm{B}_{12} \quad 0.2$ あるいは $0.5 \mu \mathrm{g}$ 経口投与した場合の蔂便 


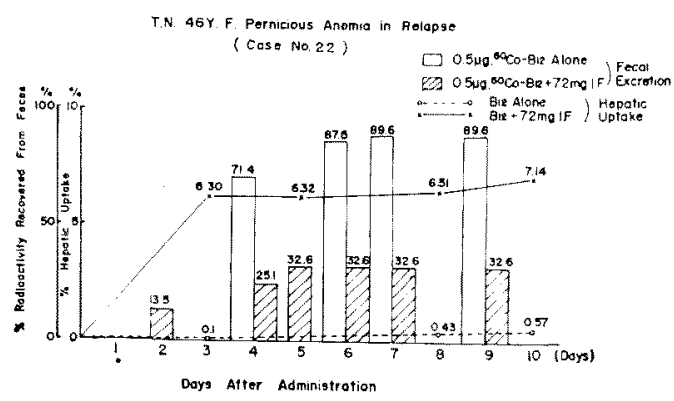

図 1. Fecal excretion and hepatic uptake.

中放射能排泄率は14.4 41.2\%，平均 $29.0 \%$ で， 平均 $71 \%$ 方吸收せられる。正常例19例に60 $\mathrm{Co} \mathrm{B}_{12}$ $0.5 \mu \mathrm{g}$ を経口投与し， Schilling試験を行なつ た場合の尿中放射能排泄率は 5.1 27.6\%，平均 $17.4 \%$ あるる。また正常例 9 例の盰放射能摄取率 最高值は平均 $8.74 \%$ ある。

2）墨性督血

悪性負血患者では，放射性 $\mathrm{B}_{12}$ 單独経口投与の 場合， $\mathrm{B}_{12}$ の吸收は正常者に比べて著しく不良

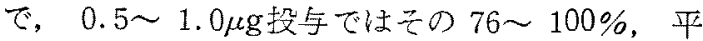
均 $88.7 \%$ 染便中に排湈せられ，平均 $11.3 \%$ しか 吸收されない（しかし放射性 $\mathrm{B}_{12}$ と内因子源（正 常人胃液, ブタ幽門部胃液, プタ十二指腸液，ブ 夕胃粘膜抽出物）を问時に経口投与すると， $\mathrm{B}_{12}$ は正常者と同様によく吸取される8) 14)(図 1).こ
のことは旪椇取率試験によつても証明せられる。 またSchilling氏尿中排泄率試験によつても同様 に証明せられる。この事実加ら悪性貝血は，胃腹 中の内因子矢贡のために消化管よりのB ${ }_{12}$ の吸収 が障害せられ，B B $_{12}$ 欠乏をきたすためにおこると 考えられる。

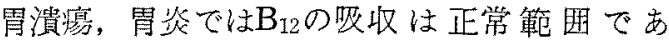
る。萎縮性胃炎，胃癌，胃ポリープにおいても， 一般にB 12 の吸收は正常である（因2）。しかし60 才以上の高年者では，尿中放射能排泄率は60才以 下の者に比べると稍々低いものが多く，60才以上 の高年者ではB $\mathrm{B}_{12}$ の吸收がや>低いことを推定せ しめる。

墨性貧血では，胃液はヒスタミン不応性無酸症 を示し，骨粘膜は胃カメラ像で著明な萎縮を示し ている，胃生検像でも著明な萎縮を示している。 覀性貧血患者にお打胃液内因子の欠走は，胃粘 膜の萎縮によるものと考えられる。

覀性貧血において亞急性春骾連合硬化症（ある いは萝状变性）による春䯣症状を合併することが あることはよく知られているが，時には貧血症状 が著明でなくして，替䯣症状のみが著明な場合が ある。ことに近年一般に貧血患者に刘して葉酸を 含む内服劑が多く用いられるようになつてからは

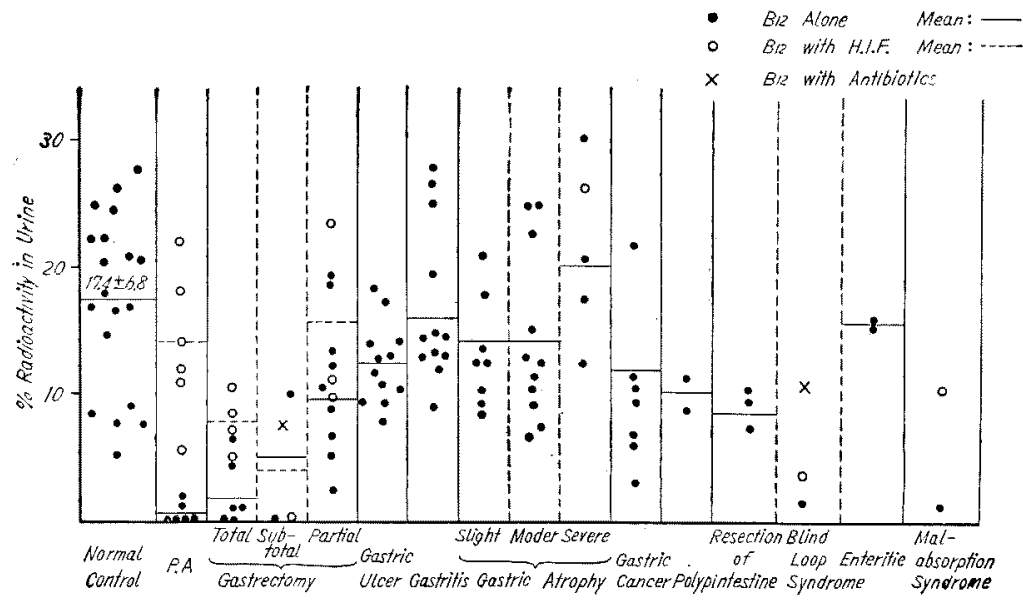

図 2. Urinary excretions of orally administered ${ }^{60} \mathrm{Co}-\mathrm{B}_{12}$ in various diseases. 
定型的巨赤芽球症を示さす，春踓症状のみが目立 つ症例が增加する可能性がある。また同時に鉄欠 豆を伴なうときは，定型的の高色性大球性筫血を 呈さないことがある。かるる例においても放射性

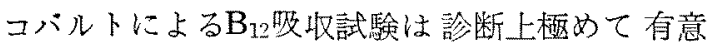
㽣である。

次にその 1 例を示す．患者は46才の女子，2〜 3 年前より歩行障害および下肢の知営障害があ る. 舌は粘膜が萎縮し, 平滑, ヒスタミン不応性

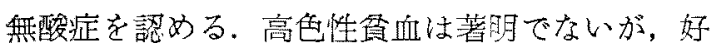
中球の核の過分葉があり，骨䯣穿刺で少数の巨赤 芽球を認める。 ${ }^{60} \mathrm{Co} \mathrm{B}_{12}$ にる試験 で $\mathrm{B}_{12}$ の吸収 障害を示す。本例は定型的高色性大球性貧血を呈 しなかつたが $\mathrm{B}_{12}$ の吸收試験の結果より，覀性貧 血に伴なう西急性佘䯣連合硬化症と䛦断し， $\mathrm{B}_{12}$ の大量投与により春道症状を軽快した。

3）胃切除者に招ける血液学的㘥察

胃全摘者において術後年数の経過とつもに大球 性ないし巨赤芽球性督血をきたすことは稀ではな (15) 18).

胃全摘の場合には，内因子を分泌する胃粘膜が 除去されるために内因子の欠如をきたし， $\mathrm{B}_{12} の$ 吸収が障害され，巨赤芽球性貧血をおこすのは当 然であるが，内因子の主な分泌部である噴門部，幽 閒部の粘膜が残存している胃部分切除者では，巨 赤来球性筫血をきたすことは稀であるとされてい る.しかし文献的にはこのような症例も相当数報 告せられている193ー23)。われわれが検查した11年 以内に胃切除を受けた126名（胃全摘５名, 胃亞 全摘13名, 部分切除108名）の末梢血液像の変化 をみると，胃部分切除者に扔いても術後年数の経 過と共に 400 万以下の負血を示す者の上京が堌加 し, 色素指数は上昇する傾向がある2425). 赤血球 平均容積は増大を来たす者が多くなり，高色性大 球性貧血をきたす傾问汃諗められる.

骨梿像においても大赤芽球の增加，顆粒球の成 熟抑制，巨核球の栓球形成障害などが一部の例に 証められた。

4）胃切除者の血液 $\mathrm{B}_{12}$, 葉酸，CF值ならびに

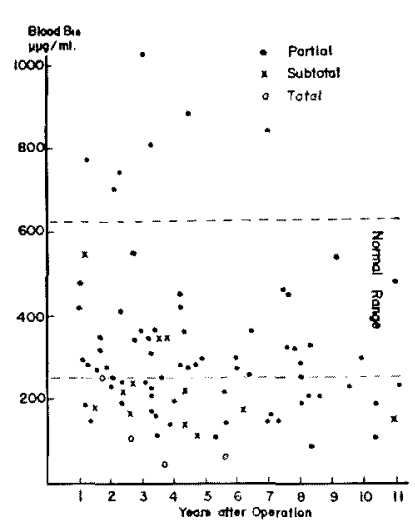

図 3. Blood $B_{12}$ in patient with gastrectomy.

$\mathrm{B}_{12}$ 葉酸負荷試験

（i）血液 $\mathrm{B}_{12}$ 値 Uchromonas法によつて測 定した胃切除者の血淮 $\mathrm{B}_{12}$ 值は部分切除例におい て注術後の経過年数と〉もに正常より低値を示す もの>割合が增加する 26 )(図 3 ). 亞全摘例ではこ の傾向は一層著明であり，全摘例では術後 2 年半 以後の例は著しく低值を示した。各群において 低下例の占める蚌合をヒストグラムで示せば，術 後の経過年数とつもに血液 $\mathrm{B}_{12}$ 值低下例の百分率 が潮次増加していくことが分る。

(ii) $\mathrm{B}_{12}$ 負荷試験 胃部分切除例に $\mathrm{B}_{12}$ 負荷試 鈳を行なつたところ，骨切除例では正常例に比べ て負荷後の血中B 12 值の上昇が少なく，また負荷後 の尿中B 12 排泄量もきわめて少ない場合が多い26). この所見性体内 $B_{12}$ 欠乏状態を示するのと考元 られる。

(iii) 血液葉酸およびC F 值血中葉酸值はお おむ初正常範国内にあつたが街後年数の経過と 共に平均值は漸次低下する傾向を示した，血中 citrovorum factor ( C F ) 值は正常上り低值を示 す場合加多く, 術後年数の経過と共に平均值が著 明に低下した。

(iv) 血液 $\mathrm{B}_{12}$ 值と $\mathrm{CF}$ 值との関缧また血中 $\mathrm{B}_{12}$ 值の低いものでは血中C F 值も低いことを認 めた。な洂血球平均容積の大きい例汪に゙，血中 C F値も低い傾向妾認めた（図4）. 


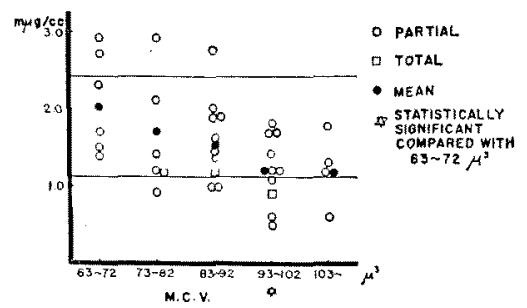

Q 4. Mean corpuscular volume \& blood of CF in patients with gastrectomy.

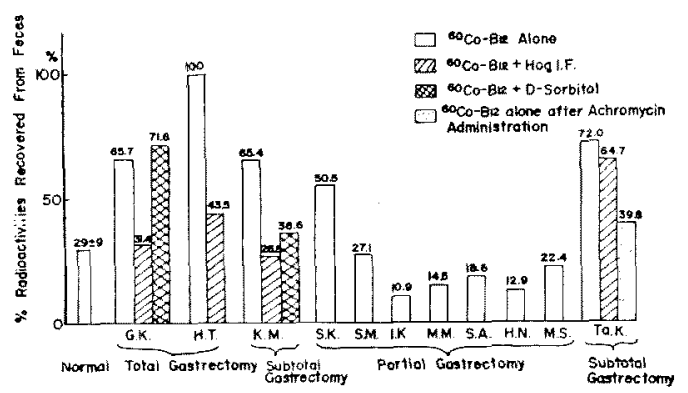

図 5. Fecal excretions in gastrectomized subjects.

（v）葉酸負荷試験 胃切除者に葉酸偩荷試験 を行なつたところ, 全摘 1 例抢よび部分切除 2 例 においては血中葉酸値の変動は正常よりや〉高值 を示し，尿中葉酸排泄量は正常域にあつたが，C F值は著明に少なかつた。このような代謝型は葉 酸からCFへの転換が障害されていることを意味 するものと考えられる25) 28)。

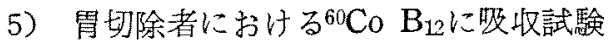

胃切除者において $B_{12}$ 吸收障害の有無を知るた めに， ${ }^{60} \mathrm{Co} \mathrm{B}_{12}$ 吸収試験を行なつた（図 5 ). 糞便 中放射能排泄率測定法による結果は，胃全摘例で は, 65.7〜 100\%の排泄がみられ，経口投与した ${ }^{60} \mathrm{Co} \mathrm{B}_{12}$ 殆ゼ吸收されていない。これに内因子 30mgを同時に投与した場合には， $\mathrm{B}_{12}$ の吸収はほ 浔正常に回復した。胃亞全摘の 1 例，部分切除 7 例のうち 1 例でも $\mathrm{B}_{12}$ 吸收障害のあることを認め た。 Schilling 氏尿中放射能排泄率測定法におい ても全摘例より程度は軽いが，亞全摘例でもまた $\mathrm{B}_{12}$ 吸收障害のあることを示している。䀒蔵放射能 摄取率測定法でも，部分切除例で䀒荿に㧍ける掑

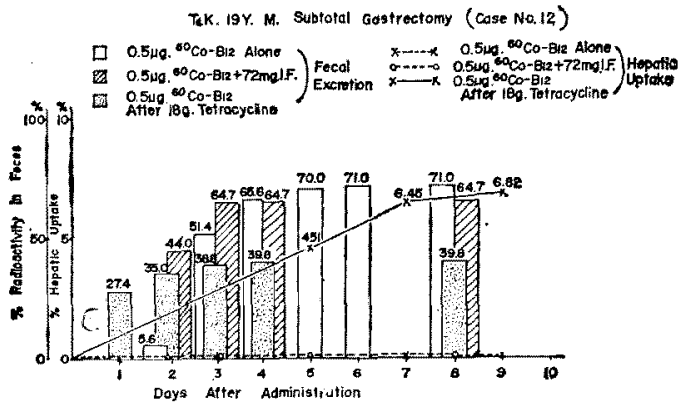

图 6. Fecal excretion and hepatic uptake.

取率が低く， $\mathrm{B}_{12}$ の吸収の瑟い場合があることを 示している。な㧍 $\mathrm{B}_{12}$ 吸收障害を示す胃朢全摘例 で， $\mathrm{B}_{12}$ の罗收が内因子の同時投与によつては改 善されず，抗生物質による治療後にはじめて改善 される例のあることを認める（図6）。

以上のようにわれわれの観察した胃部分切除 例でも胃全摘例ほモ゙著明ではないが， $\mathrm{B}_{12}$ 吸收障 害が存在し， $\mathrm{B}_{12}$ 欠记状態が微後年数の 経過と共 に著しくなることが明らかにされた。

人体においては，内因子の分泌柱として胃の 噴門部または胃底部で行なわれ，胃体部および 幽門部も多少は内因子活性があるといわれてい る29 31)。われわれの観察した部分切除例では，顕 問部ないし胃底部忹残存しているので，この部分 の欠如による内因子の欠乏は若え難い，胃部分切 除例における $\mathrm{B}_{12}$ の吸收障害は残存贯の萎絔性胃 炎による内因子の分泌(障害22)32) 34)，腸管踣係 内または妄管内における腸内細菌叢の異常発姢に 伴なう腸内細菌のB 12 破壊ないし摄取などによる ものと考えられる。われわれの観察においてX線 的に残余胃部に胃炎像を諗めることが多く，また 胃カメラで萎鏥性胃炎の像を比較的高率にみるこ となども，胃部分炀除例の $\mathrm{B}_{12}$ 吸收障害に胃粘膜 萎縮方関与していることを推定せしめる。

また部分切除例において，内因子の同時投与で $\mathrm{B}_{12}$ の吸收障害引改善されず，抗生物質の投与に よる沿療後に $\mathrm{B}_{12}$ の吸収が正常化する例のあるこ とは晹内細菌埌 が $\mathrm{B}_{12}$ の吸収障害に関与している ことを示唆する。 
6) $\mathrm{B}_{12}$ と葉酸, Citrovorum factor との䦰係 つぎに胃切除者の血中 $\mathrm{B}_{12}$, 葉酸, $\mathrm{CF}$ 值の関係 について考察するに，われわれの胃切除者に沶い て，血清 $B_{12}$ 值の低下と血清 C F 值の低下の間に ある程度の相関が認められたことは， $\mathrm{B}_{12}$ 欠无に より葉酸よりCFへの転遺が䧗害されること，

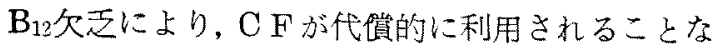
どによるものであるう35～433)，胃切除者に行なつ た葉酸色荷試駼に势いて，血液葉酸值の上䄯が著 明で，氺中葉酸排泄量が多い区面，尿中 C F の排 泄量が少ないことも、葉酸より $\mathrm{C} \mathrm{F}$ 一の転換障害 のあることを推定せしめる。

IV、消化管よりの葉酸の吸収

葉酸は生体内でC Fに転捡され $\mathrm{B}_{12}$ ともをに核 酸代謝, 造血機能に重要な関综をもっており, 葉 酸の欠炎あるいは利用障害に上り巨赤芽球性貧血

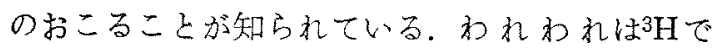
標識した葉酸を用いて消化管よりの葉酸の吸收を 研究した7)44).

葉酸吸收試験として予的非放射性の葉酸15mgを

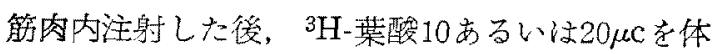
重 $1 \mathrm{~kg}$ あたり $40 \mu \mathrm{g}$ の非放射性葉酸とつもに経口 投与し，24時間尿中 ${ }^{3} \mathrm{H}$-葉酸排泄率ならびに䔬便 中3H-葉酸排浛率を測定した。

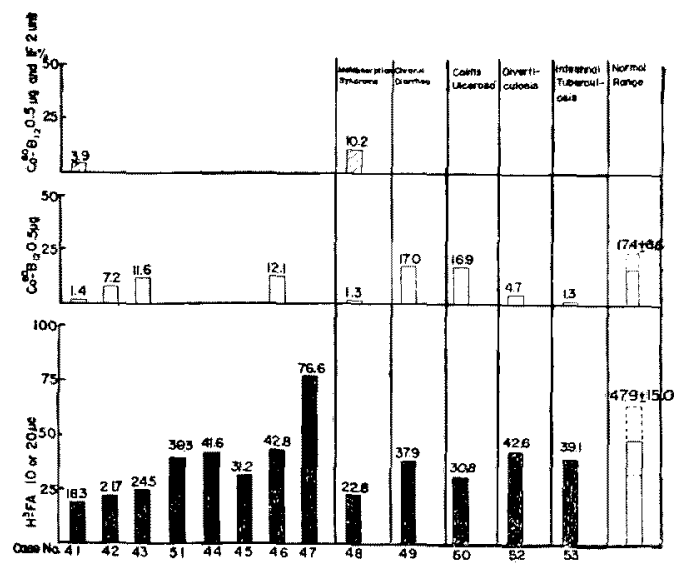

図 7. Urinary excretion of ${ }^{3} \mathrm{H}-\mathrm{FA}$ and ${ }^{60} \mathrm{Co}-\mathrm{B}_{12}$ in intestinal diseases.

正常例10例に扔ける3H-葉酸吸收試魵の結果は 尿中24㭙間排泄率平均 $47.9 \%$ ，そのうち 3 例につ いての筫便中排泄率は平均 3.5\%である(図7).

$\mathrm{B}_{12}$ 吸收障害のある覀性初血では3 H-葉酸経口投 与後の尿中 $3 \mathrm{H}$-葉酸排洺率や>低く, 葉酸の軽度 の吸収障害が推定せられた（图 8).

胃全摘列では, 3H-葉酸経口投与後の尿中 $3 \mathrm{H}-$ 葉 酸排泪率は 3 例已も正常あるいは正常よりや>高 值を示したが，胃部分切除例では 4 例中 2 例にお いて正常より低值を示し、葉酸の軽度の叒收障害

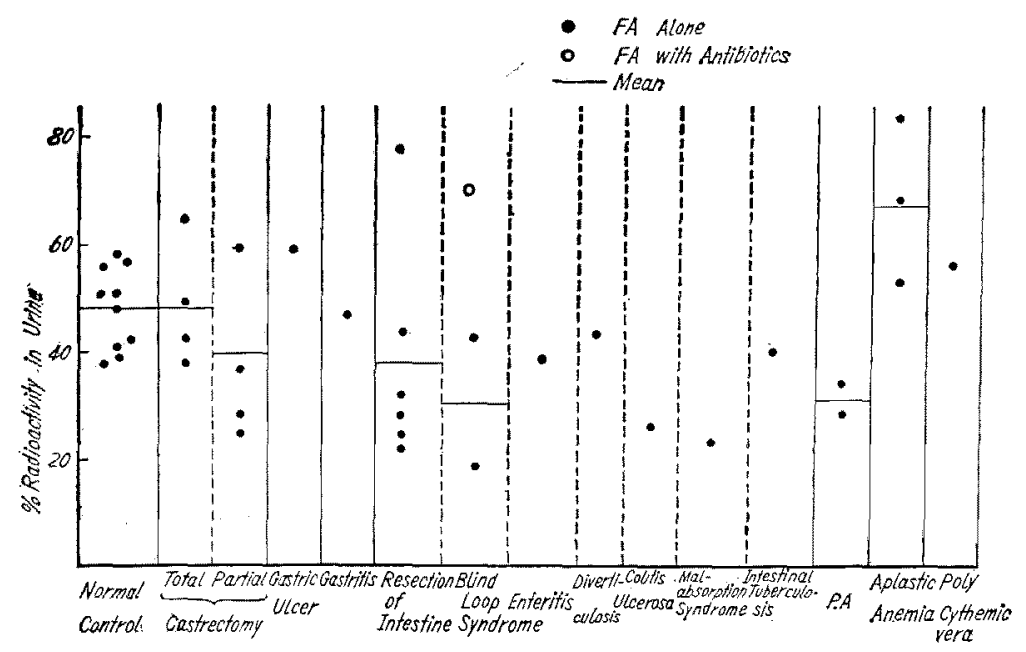

图 8. Urinary excretions of orally administered $\mathrm{H}^{3}-\mathrm{FA}$ in various diseases 
が推定せられた。盟炎および胃癌の各 1 例では尿 中 $\mathrm{H}$-葉酸排泄率は正常であつた。

小腸疾秘で注小晹部分切除例，腸々肠合例等 8 例中 3 例において， $3 \mathrm{H}$-葉酸経口投与後の尿中排 泄率が正常より低く葉酸の吸收障害が推定せられ た。またmalabsorption syndromeの 1 例におい ても,同様に3H-葉酸吸収試験に上り葉酸の吸收障 害が認められた。なおこれらの葉酸吸収障害を示 す症例では60 Co $\mathrm{B}_{12}$ にるSchilling 試験でも $\mathrm{B}_{12}$ の 吸收障害が認められ，これは内因子同時投与によ り改善される場合と古まり改善されない場合と加 あつた，後者の例は腸結核による小腸狭窄のため に3简所に亘り腸に吻合術を受けblind loop syndrome 呈せる症例である. 入院時 $\mathrm{H}$-葉酸㧍よび ${ }^{60} \mathrm{Co} \mathrm{B}_{12}$ による吸收試験で某酸および $\mathrm{B}_{12}$ の吸收 障害吢認められ， $\mathrm{B}_{12}$ の吸收は内因子同時投与に よつても改善されなかつたが抗生物質による治療 後は葉酸, $\mathrm{B}_{12}$ とに吸收が正常化された。これは blind loop syndromeにおける腸内細菌丵の異常 が抗生物筫治㬌により是正された結果と考えられ る。本例では骨链像においてmegaloblastoidが 30.5\%に認められた。本例では消化管よりの出血 による鉄欠无も同時に存在し， $\mathrm{B}_{12}$ ，葉酸の吸収 障害之相俟つてdimorphic anemiaを呈したもの と思的れる。本例の貧血注鉄，某酸， $\mathrm{B}_{12}$ の非経 口的投与により次第に回復に向い, 最初鉄剂單独 投与により堌大した赤血球平均容積も $\mathrm{B}_{12}$ ，抗生 物質，葉酸に上る治療後は次第に樎小している。

V. 巨赤芽球性貧血の発生機序に関する実験 的研究

$\mathrm{B}_{12}$ と葉酸とは，ともに核酸ないし核蛋白代謝過 程における作用物質であり，その久そによつて血 球ことに赤血球の正常な生成および成熟が障害せ られ，いわゆる系芽球性貧血をきたすことが知 られている，われわれは1025345) 日赤芽球性貫血の 発生機序を解明するため, 生後 7〜10日の幼若 $\mathrm{AD}$ 柔モルモットにB 12 , 葉酸扔よび葉酸のCitrovorum factorへの転換を促進するといわれているビタミ
表 2. Blood \& bone marrow pictures in $\mathrm{VB}_{12}$, PGA, VC deficiency (guinea pigs).

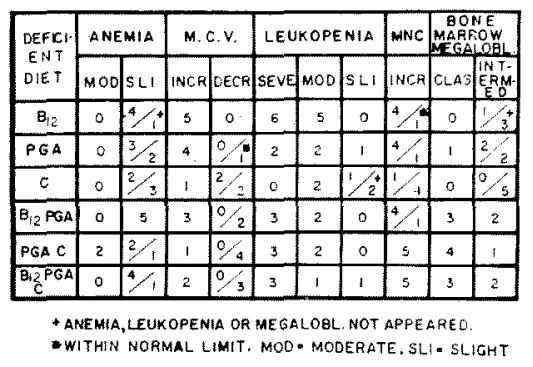

ンCの單独欠乏食, あるい性襩合欠乏食を与えて, 以下の観祭を行なつた。

$\mathrm{B}_{12}$ ，葉酸の單独欠炎あるいは $\mathrm{B}_{12}$ ，葉酸，Cの複 合欠乏においては赤血球数および血出素量の軽度 減少を諗めた (表 2 ). 網赤血球の減少, 赤血球平 均血色素量の上昇老見た。赤血球平均容積の増大 すなわ方球性筫血の傾向，白血球の減少を認め た。また好中球の核右方移動，烃球の減少などを 認めた，骨䯣においては，巨赤芽球あるいは移行 型巨赤芽球の出現, 顆粒球の生成障害および成熟 抑制の像を諗めた。これらの变化は $\mathrm{B}_{12}$, 葉酸單独 欠乏群よりも複合欠乏群において一層著明であつ た。

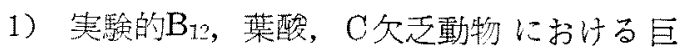
亦芽球

恶性貧血の場合にみられる巨赤芽球は位相差顥 微鏡像において，正赤芽球に比へてて先ず塩基性の ものでは胞体および核が大きく,核膜は薄く,結節 状肥厚が少なく，また榜質が微細顆粒状であるこ と，核小体が草大花状を呈すること，核小体の 泡状構造が豊富なこと等が特幑的である。多染性 のもの，抢よび正染性のものは核，盷体共にその大 きさを減ずる度合が少なく，核質は濃縮すること なく斑点状を呈する。また核膜は薄く，小結節状 肥厚も殆どない， $\mathrm{B}_{12}$ ，葉酸， $\mathrm{C}$ 久炎モルモット の赤芽球を塩基性，多染性のものにあつては上述 の如き巨赤芽球の特長をよく表わしている.

電子顕微鏡による観察 46 )では，複合欠走群の幼 
若赤芽球においては，核質は均等存分布を示さ ず，数力所に不規則な㠜舅を形成するが，この間 に介在する電子望度の高い核仁とは容易に識別し うる。胞体内にはRNA顆粒が箅に分布する。小 胞体は概して无しく，網管状ないし小空胞状を呈 する. 系粒体は一般に多く，主として円形ないし 梢円形で正常モルモットの塩基性赤牙球のそれに 比しや〉小さく緻滵な愿を呈する.

2) B 12 ,葉酸，C矢王動物に扔ける神経組織の 変化

悪性貧血において神経組織の障害をさたし，亞 急性奉髄連合硬化症の症状を呈することがあるこ とはよく知られている。われわれの動物実験の成 績によると, 春䯕前角細胞のNissle substanceに はB 12 單独欠无群の一部において在，融解の像 を認め, tigrolysisを示した。また 複合久之群においてもtigrolysis 証めた。

3) 血液㧍よび造血藏器のB 12 , 葉酸, Citrovorum factor量

血液 $\mathrm{B}_{12}$ 值は， $\mathrm{B}_{12}$ ，C單独欠无群予よび $\mathrm{B}_{12}$ ，葉酸， C複合欠泛群のいず机おいても低下を示し， ことに襩合欠㝎群では生存日数が短く，欠走食投 与期間が短いにも拘らず，血液 $\mathrm{B}_{12}$ 值の低下が著 明で亦つた。 な㧈血液 $\mathrm{B}_{12}$ 值の低下を示文例では 末梢血液中の赤血球数，血色素量の減少を未だ認

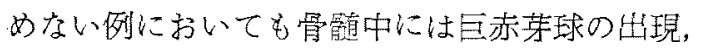
過分葉好中球の出現を認めた。骨髄の $\mathrm{B}_{12}$ 量も $\mathrm{B}_{12}$ 單独欠乏, $\mathrm{B}_{12}$, 葉酸, $\mathrm{C}$ の複合欠贡群で注減少を

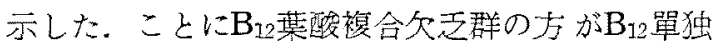
欠炎群よりも骨髄 $\mathrm{B}_{12}$ 量の減少が著明であつた。

骨髄の葉酸，C F 量は $\mathrm{B}_{12}$ 單独久㐊群では正常 と殆ど差がないが， $\mathrm{B}_{12}$ 、葉酸，C複合欠走群では 著明に減少した。ことに定型的な巨赤芽球の出現 を見た例においてはこれらの減少が著明であつ た.

4) 造血缄器核酸分画の $32 \mathrm{P}$ 交替率

$\mathrm{B}_{12}$ あるい注葉酸の單独あるいは複合久元動物 では骨䯣に拈けるDNA，RNA の $32 \mathrm{P}$ 交替率は 著しく減少している25)47（因9）。また葉酸單独欠

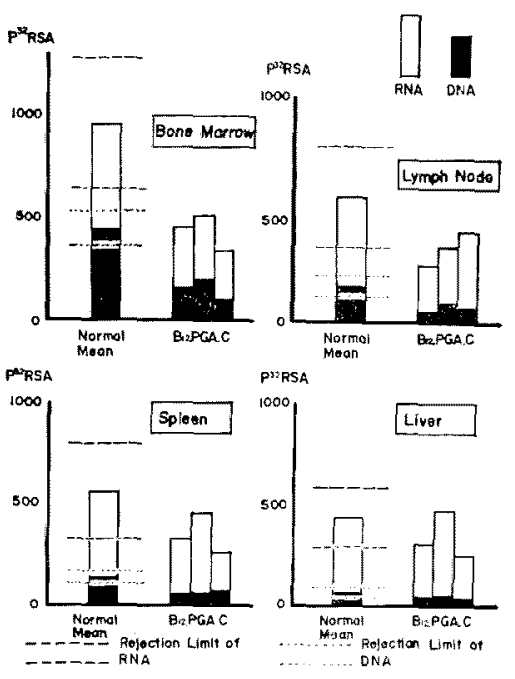

図 9. ${ }^{32} \mathrm{P}$ incorporation into RNA and DNA (guinea pigs with $\mathrm{B}_{12}, \mathrm{PGA}, \mathrm{C}$ deficiency).

王上葉酸、C複合欠坠上老比較すると，後者の方 が32P交替率の減少が著しいようで女る。の成續 はB 12 , 葉酸が核酸代謝に重要な関係のあること志 示すものであり， $\mathrm{B}_{12}$, 葉酸欠乏動物における赤芽 球の成熟障害, 顆粒球㧍よび栓球の生成および成

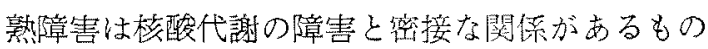
と考えられる。

5）顕微分光測定法に上る巨赤芶球の DN A 定 量

われわれはB 12 葉酸欠泛時における巨赤芽球の 発生機序の一端を明らかにするために，さらに目 赤芽球の榜酸代謝老細胞レベルて梌票せんと試み た.

すなわち悪性筫血㭧者骨跹抢よび $\mathrm{B}_{12}$ ，葉酸，C

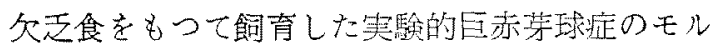
モットの骨榳を採取し，その塗抹標本にFeulgen 染色を施し，テレビション紫外總顕微鏡および附 属の顕徽分光光度計を用い, Feulgen染色の最大 吸収波長である $560 \mathrm{~m} \mu$ の波長で赤芽球の DNA 量を測定した。

治潦前の悪性盆血患者の正染性巨赤芽球ではD $\mathrm{NA}$ 量は正常例の正染性正赤芶球と大差なく，穴 の平均值はリンパ球のそれと汪ぐ等しい。すなわ 
ち2n（diploid）である，墨性貧血患者治療前の 好塩基性および络染性巨赤芽球では，これに反し て平均 DNA量は正常例の好塩基性および多染性 赤牙球に比べてや〉多い，かつこれは治療後に減 少して正常赤芽球の值に近づく（表 3 ）.

表 3. DNA content of human megaloblasts.

\begin{tabular}{|c|c|c|c|c|c|c|}
\hline & \multicolumn{3}{|c|}{ orthactromatle } & \multicolumn{3}{|c|}{ baso polyohromatophilic } \\
\hline 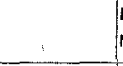 & $\begin{array}{l}\text { Na of } \\
\text { Nuctei: }\end{array}$ & $\begin{array}{l}\text { Nucloor } \\
\text { Aroo (w) }\end{array}$ & $\left.\begin{array}{c}\text { ONA Contes } \\
\text { arbitrary } \\
\text { unity }\end{array}\right)$ & No, & $\begin{array}{l}\text { Nuclear } \\
\text { Area }\left(\omega^{2}\right)\end{array}$ & $\begin{array}{l}\text { ONA Coment } \\
\left(\begin{array}{c}\text { orbltrary } \\
\text { units }\end{array}\right)\end{array}$ \\
\hline Normal & 6I & $38.2 \pm 0.8$ & $2,58 \pm 008$ & 58 & $68.0 \pm 2.1$ & $406 \pm 0.13$ \\
\hline P.A. untreoted & 29 & $400 \pm 15$ & $2.90 \pm 012$ & 73 & $89.6 \pm 2.0$ & $530 \pm 0,17$ \\
\hline - treated & 50 & $41,1 \pm 1,1$ & $2,47 \pm 0.07$ & 60 & $74.5 \pm 2.7$ & $3,93 \pm 0,09$ \\
\hline $\begin{array}{c}\text { Mogalobiastic } \\
\text { Anemia }\end{array}$ & 49 & $37.1 \pm 09$ & $3.23 \pm 013$ & 65 & $80,0 \pm 1.9$ & $580 \pm 0.14$ \\
\hline Lymphocytes & 38 & & $2.48 \pm 0.71$ & & & \\
\hline
\end{tabular}

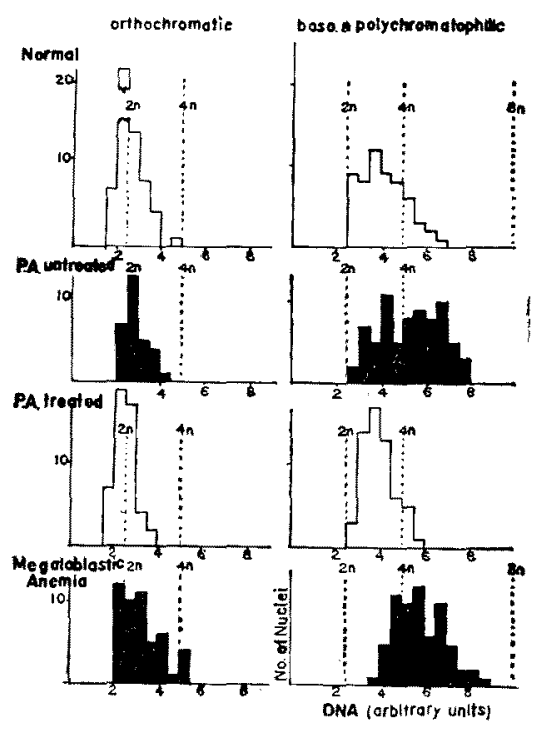

図10. DNA content of human megaloblasts.

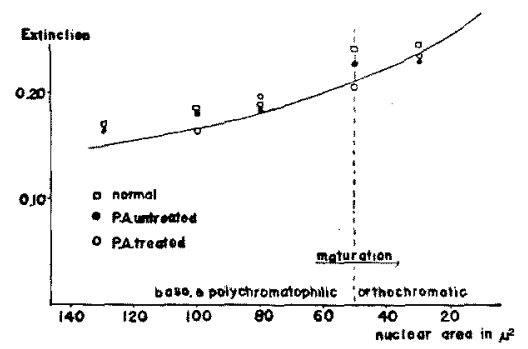

図11. Change of extinction with cell size.
赤芽球DNA量の分布をhistogramでみると， 正染性のものは要性貧血治療前および治療後の巨 赤芽球および正常例の正赤芽球の何れにおいても peakは2nの附近にあり，その分布もほら゙均一で ある。これに反して悪性貣血の好塩基性および多 染性巨赤芽球ではD DA 量 のpeakは $2 \mathrm{n} \sim 4 \mathrm{n}$ の 中間にあつて，正常例の好塩基性および多染性正 赤芽球よりも右万に偏し，加 $4 \mathrm{n}$ 以上のDNA 量を有する細胞が正赤芽球に比へて多い（図10). かつ第 1 例の雭性貧血では治療後にDNA量分布 の幅が狭くなり，4n以上の細胞が減少し，代つ て $2 \mathrm{n} \sim 4 \mathrm{n}$ 間の細胞が堌加している.

次に赤芽球の核の大きさと平均吸收率の関绿を みると，正常例，悪性頒血治療前，治療後の3 者何れも赤芽球が成熟し概が小さくなるにつれて extinctionは一様に増加している（図11），従って 同一の核面積の正赤芽球と巨赤牙球はDNA量に 差がないとい〉得る。しかし巨赤芽球においては， 一般に個々の細胞の核面積が大きくなり，沿療後 には縮小して正常に復帰する傾向を示している。 促つて正赤芽球でも巨赤芽球でも核の單位面積当 りのDNA量には差はないが，巨赤芽球は一般に 核面積が大きいために, cell population当りのD $\mathrm{NA}$ 量泟赤芽球よりも多いと考えられる.

さらに赤芽球の成熟に伴なう DNA 量の变化を みると, 正常则, 悪性筫血治療前, 治療後の 3 者 何れも同様に正赤芽球，巨赤芽球とも成熟し核が 小さくなると〉もに, DNA 量は一様に減少して いる(区12)。

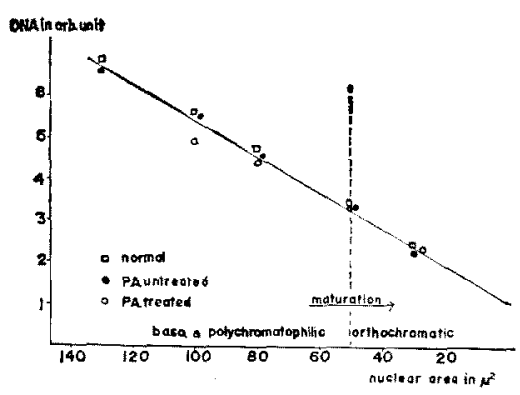

図12. Decrease of DNA with maturation. 
$\mathrm{B}_{12}$ ，葉酸， $\mathrm{C}$ 複合欠乏食䬣で飼育した奻若モル キットの巨赤芽球についても同様の梌索を行なつ た結果，悪性貧血の巨赤芽球と同じく，正染性巨 赤芽球では正染性正赤牙球と同様 DNA量は $2 \mathrm{n}$ 附近にpeak有し，DNA 量分布のhistogram ほぶ同様であつた（図13）。

一方好塩基性および多染性巨赤芽球では，平均 DNA量は正常に比べて多く，DNA量分布の histogramでは正赤芽球のpeakが $2 \mathrm{n} \sim 4 \mathrm{n} の$ 中 間にあるのに対して，久泛勤物ではpeakが 4 几に あり、これを中心 $2 \mathrm{n} か ら 6 n$ 分布するもの あるいはさらに右方に偏して，8n附近にまで分 布するものがある。このDNA量增加に刘応して 人間の巨赤芽球の場合と同样核面積が增加してい る(表4).

6）目亦芽球の分裂能，成熟能㧍よび DNA合

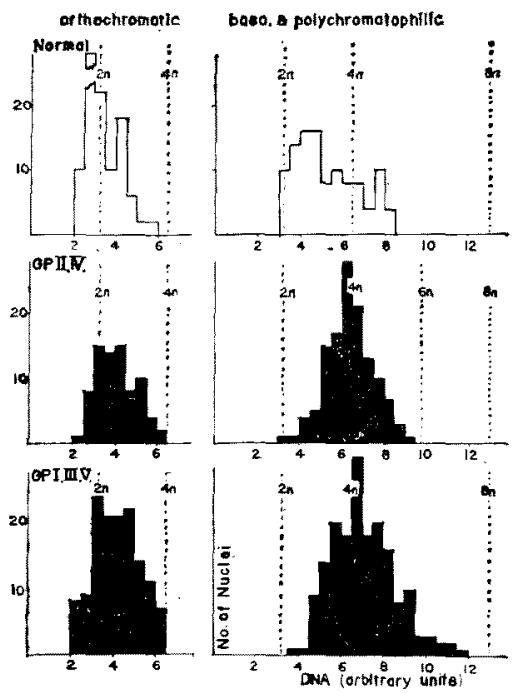

図13. DNA content of guinea pig megaloblasts.

坟 4. DNA content of guinea pig megaloblasts.

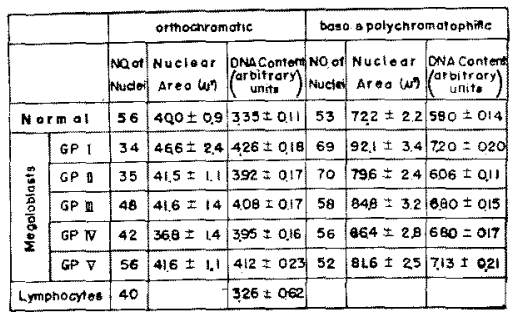

昭和39年12月10日
成能

悪性賈血患者の骨髄ならびに前に述へた実験的

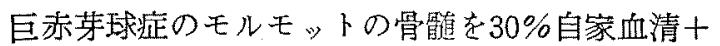
$70 \%$ Hank 氏溶派を用いてroller tubeで培養し， 赤芽球の分裂能，成熟能および DNA合成能を観 察した。

われわれが 6 例の悪性負血患者について治療前 後の赤芽球のmitotic indexを梌討したところで は,治療前には正常に比へてmitotic indexがや> 低く, $\mathrm{B}_{12}$ による治療後負血の回復と〉もにmitotic indexは上舁する（四14）。また24時間扔よび48時 間培養した恶性貧血巨赤芽球について，maturation indexを求めたところ，正常血清と〉もに培 養した場合には患者自身の血清と〉もに培養した 場合に比べてmaturation indexの上昇を諗めた。

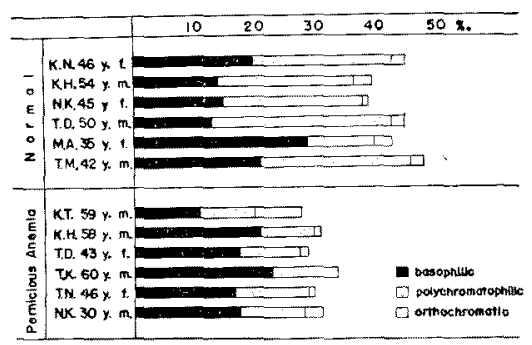

图 14. Mitotic index of megaloblasts and normoblasts.

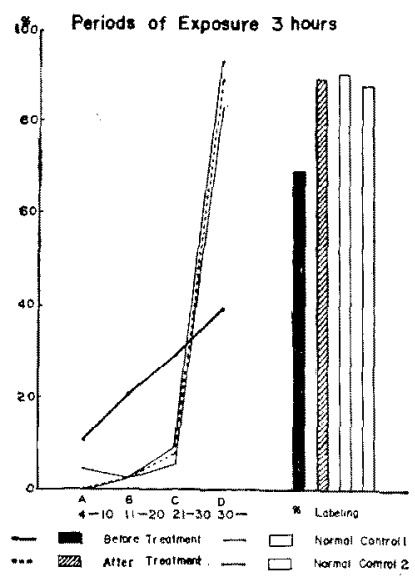

区15. Incorporation of ${ }^{3} \mathrm{Ht}$-hymidine into megaloblasts of a patient with pernicious anemia (K.T. 59y. Male). 


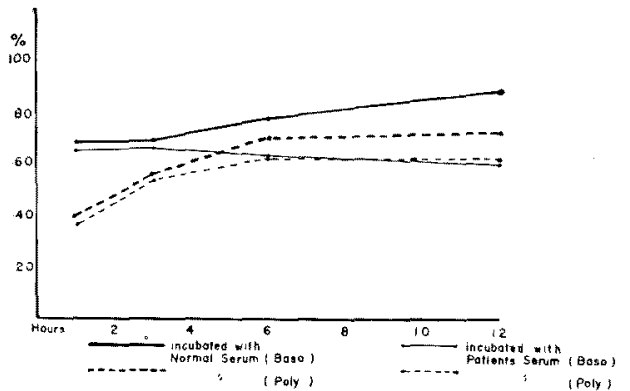

区16. \% labeling of incorporation of ${ }^{3} \mathrm{H}$-thymidine into megaloblasts of a patient with pernicious anemia (K.T. 59y. Male).

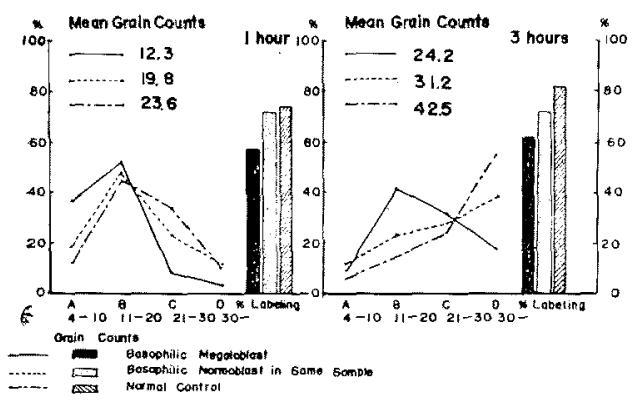

国17. Incorporation of ${ }^{3} \mathrm{H}$-thymidine into megaloblasts of $\mathrm{B}_{12}, \mathrm{FA}, \& \mathrm{C}$ deficient guinea pigs.

また治療後のものでは治濝前に比べてmaturation indexの上昇が諗められた。

${ }^{3} \mathrm{H}$-thymidineによるautoradiography ${ }^{48) て ゙ は, ~}$ 治療前の悪性貧血患者の骨踐巨赤芽球は標識細胞 百分率，粒于数ともに正常例に比へて低值を示 し，DNA合成能の低下を示晙したが，治療後は 正常例とほメ゙同様になつた（図15）。

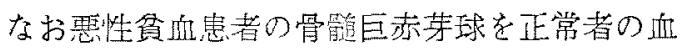
清と共に培養した場合には，患者自身の血清と共 に培養した場合に比べて，塩基性および多染性巨 赤芽球の ${ }^{3} \mathrm{H}$-thymidine による標識細胞百分率の 增加を認如た（図16).

$B_{12}$, 葉酸, $\mathrm{C}$ 複合欠乏モルモットの骨㖪培着に おいても塩基性巨赤芽球の3 $\mathrm{H}$-thymineに上る標 識細胞百分獄抒よび粒子数は正常モルモットに比 ベて低值を示し，DNA合成能の低下を示晙した (図17).
以上われわれの得た成績では，巨赤芽球におい てはDNA 合成能の低下，榜分裂能の低下，成熱 能の低下，DNA量の増加が推定される. 巨赤牙 球においてDNA合成能の低下が西るにも拘ら ず，DNA含量が増加していることはReisner ${ }^{49}$ らの推論するごとく， one-carbon unitsの転移

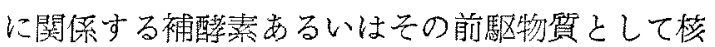
酸合成に重要な関係を有するB $\mathrm{B}_{12}$ あるいは葉酸の 欠乏のために核分裂に先立つDNA合成の過程で 何らかの障害, 例克ばDN A 合成期間の延長，あ るいは合成速度の遲正があつて，緩慢にDNAが 合成され，4n值に至つても椟分裂の障害のため 核分裂が開始せず，DNA含量の多い細胞の占め る割合が多くなるものと考えられる。

\section{VI. 内因子の性状}

前述のように悪性貧血は消化管よりのB 12 吸收 障害によってB 12 欠炎をきたすため抗こるもので あり，消化管より生理的量のB 12 方吸彼されるた めには，内因子の存在が必要なとと今日殆ど疑 いのない事実である。1948年B 12 が発見されるに 及九で，Castleの提唱した悪性貧血に㧍ける内因 子技上び外因子のうち，外因子が $\mathrm{B}_{12}$ あること が制明し，往来謎とされていた悪性貧血の発生機 序の解明に大きな光明がもたらされたので，残る 一方の内因子の究明に多くの研究者の努力が向忛

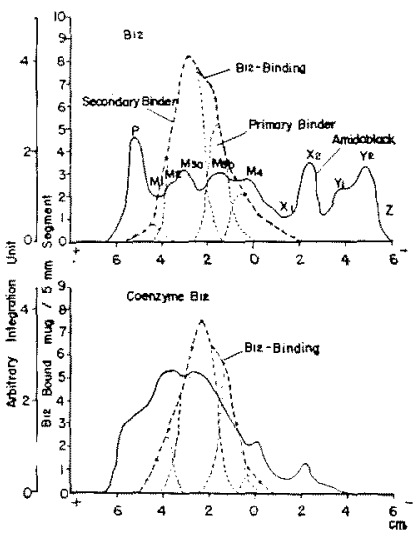

Q18. Electrophoretic pattern of $B_{12}$ \& coenzyme $\mathrm{B}_{12}$ binding with normal human gastric juices. 
られたのは当然である50)。

1) 内因子と $B_{12}$ 結合能

内因子は今日まだ純粹な物質として分離されて いないか，内因于と的結合能との間に密接な関 係があるこは今日一般に認方ら㣗ている1031)。

内野, Glass氏(51) -54)らは人の胃液のB $\mathrm{B}_{12}$ 結合能を 指標として内团子の研究を行なつた。

生の正常胃液を用いた胃液B $B_{12}$ 結合能電気泳動 四では，陽檕側で原点に近く一つの峰 (primary binder), 壹くに他の峰 (secondary binder) が 認めら礼る(図18). 無酸胃液では両者の中間部に 峰 (intermediate binder) が認められる。これ らのB結合峰を蛋白量ならびにPAS染色量 と此較すると，蛋的ではprimary binderはGlass $の \mathrm{M}_{3} \mathrm{~b}$, secondary binderは $\mathrm{M}_{2} に$ 一致する.つ ぎに胃液内の各結合能の特性をみる, 正常胃液 では, primary binder そsecondary binderがも つとも大きい結合能を示し，ヒスタミン不灾性無 酸症および恶性貧血ではintermediate binder が 主要部分を占め，一部にprimary binderを少量含 んでいる，加熱による影響をみると，内因子は加 熱によりその効力を失うことはよく知られている が, primary binderはいずれの pHでも加熱によ り完全に破填され， secondary brinderはpH 7.0 における加熱では少し残り，pH 1.50加熱では殆 ぞ破䪺される。 intermediate binderはいずれの pHでもや小抵抗性を示す。

以上の成績方ら内野らは胃液的結合能の基本 になるものは primary binderで, secondaryお よび tertiary binderはその分解産物であるとし ている.

\section{2) 内分于分汹相胞}

内因子を分泌する細胞については今日なお明ら かではないが，内野54はautoradiographyにより 胃粘膜各細胞のB 12 結合能を娭査した。この䅜の 研究としては, Niewegら55)の報告があるが, 内野 は白鼠の胃を飽和硫酸アンモンで固定した後 $60 \mathrm{Co}$ $\mathrm{B}_{12}$ を作用せしめてautoradiographyを行なつた 結果, 胃底部粘膜梁層の主細胞の多く存在する

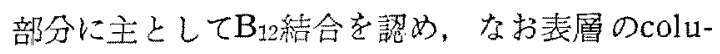
mner cell層にも軽度にB 12 結合を証明した。この 所見から主細胞が内因子の主な分泌細胞ではない かと考えられるが，人胃粘膜についてさらに検討 が必要である。

\section{3）内因子の精製}

人の胃液あるいは趼胃粘膜から内团子を分離精 製する試みについては，1933年Helmerら56)の報 告以来多くの研究50)57)58759>があるが, 最近内因子 のB 12 結合能を指標として, 種々のcolumn chromatographyを用いて内因子を分離精製する試み が行なわれている(60) 63)。

われわれは正常人胃腹の凍結乾燥したをの10 mg pH 9.00 borate buffer $1 \mathrm{ml}$ に溶加し, ${ }^{60} \mathrm{Co}$ $\mathrm{B}_{12}$ 加えてsephadex-G-25 columnにかけて， borate bufferで溶出し，各分画の放射能を測定 すると共にWarburg \& Christianの方式により 蛋白量を算出した，その結果正常人胃液を用いた 場合には，二つのpeakが得られるが，各分画を 透析して再び放射能を測定すると，第二のpeak は消失する（因19）。このことから第二のpeakは 遊離の ${ }^{60} \mathrm{CoB}_{12}$ によるものと考えられる。

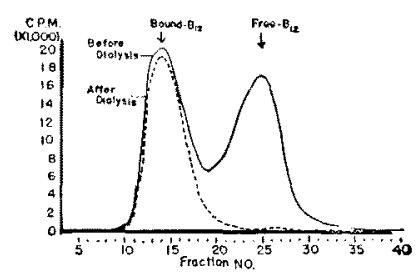

图19. Sephadex-G-25 column chromatography N.H.G.J. $10 \mathrm{mg}$ borate buffer pH 9.0 .

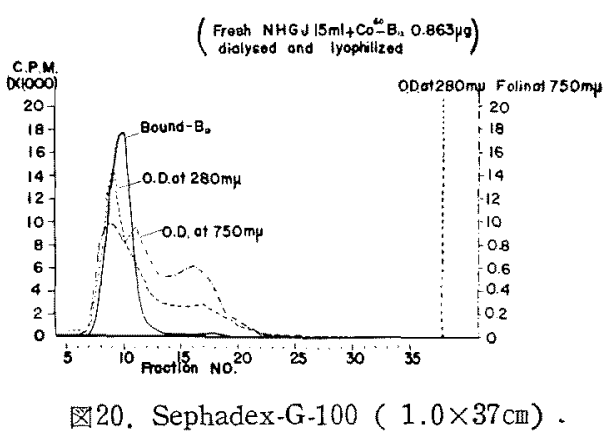




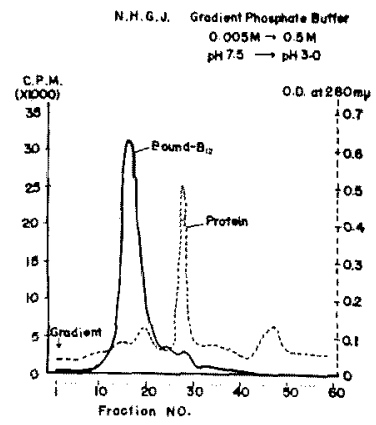

济21. DEAE-cellulose column chromatography $(1.0 \times 30 \mathrm{~cm})$.

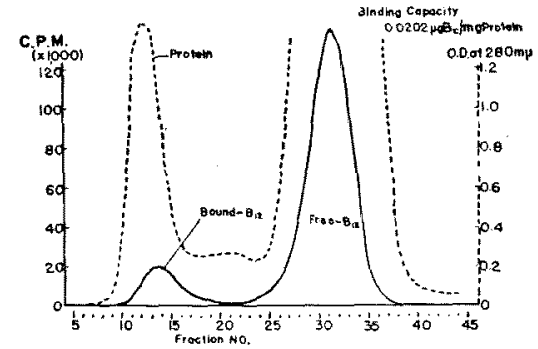

冈22. Sephadex-G-100 ( $2.0 \times 50 \mathrm{~cm})$ P.A.G.J. 50mg (T.O. 43y. Female).

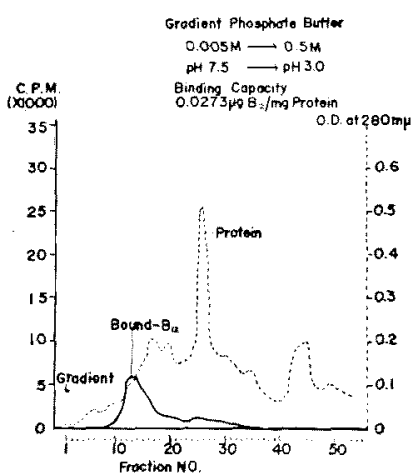

7 23 . DEAE-cellulose column ( $1.0 \times 30 \mathrm{~cm})$ chromatography P.A.G.J. 50mg (T.O. $43 \mathrm{y}$. Female).

次に新鮮胃液に ${ }^{60} \mathrm{Co} \mathrm{B}_{12}$ 週飽和に加え, 透 析徣凍結乾喿した \& の $10 \mathrm{mg}$ tsephadex-G-100 columnに加たところ透析しないものでは， $\mathrm{B}_{12}$ 結合能に二つのpeakが認められるのに対して， 透析した場合には放射能測定で第一のpeakのみ 残り，280m $\mu$ にけるoptical densityの測定で

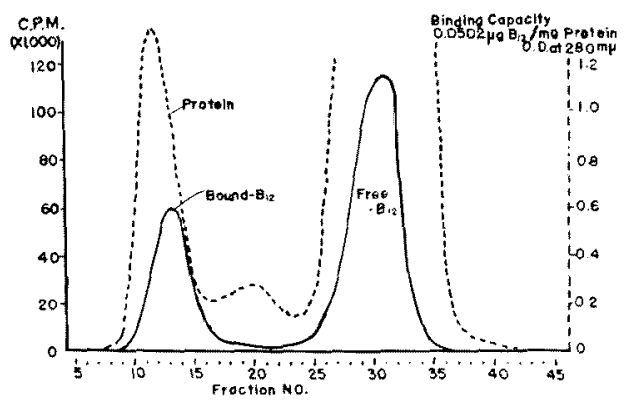

图24. Sephadex-G-100 ( $2.0 \times 50 \mathrm{~cm})$ H.F.A. G.J. $50 \mathrm{mg}$ (K.T. 33 y. Female).

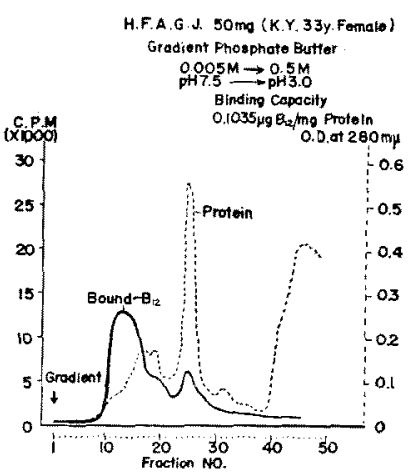

図25. DEAE-cellulose column chromatography $(1.0 \times 30 \mathrm{~cm})$.

8第一のpeakのみ残つた（因20).

そこで正常人贯液，七スタミン不応性無酸正患 者胃液，要性貫血㭧者胃液につWて， ${ }^{60} \mathrm{CoB}_{12}$ 結 合能を指標として，内因子の分部精製を行なつた

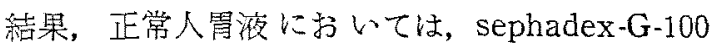
においてを第一のpeakは高かつたが，DEAEcellulose columnに拉てを一つの高 W peakか

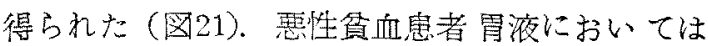
sephadex-G-100, DEAE-celluloseの場合, とをに

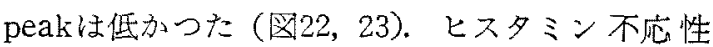
㥜液においては，正常と要性䝨血之の中間を示 した (国24，25). な孙DEE-cellulose column chromatography徭において，要性賁血靑者の胃

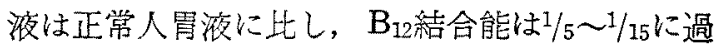
ぎなかつた。

さらに以上の方法で正常人胃液凍乾燥物 100 


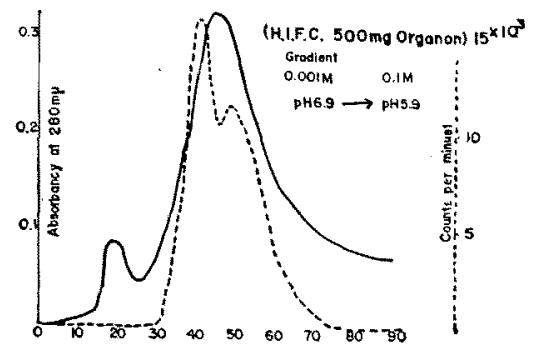

26. DEAE-SF column chromatography.

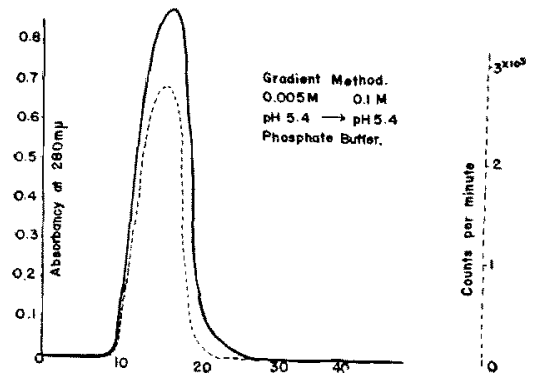

图27. C.M.C. column $(1 \times 30 \mathrm{~cm})$ (H.I.F.C.: organon).

林より得られた最終産物2.83mgを用いて, Schi一 lling法により悪性貧血患者における内因子活性 を検したところ，渚明な活性を有することを認め た。この精製物の物理化学的性状についてはさら に検討中である。

4）豚胃粘膜上り抽出された内因子製剂の精製 われわれはさらに䀠胃粘膜より抽出された内因 子製剤を用いて内因子の精製を試みた。すなわち

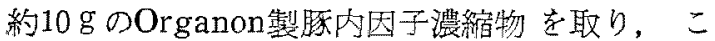
れに ${ }^{60} \mathrm{Co} \mathrm{B} \mathrm{B}_{12}$ 約 $0.3 \mu \mathrm{g}$ を加えて栖識し，Holdsworth ${ }^{63}$ の方法に準じてDEAE-SF celluloseを用 いてBatch法により $\mathrm{B}_{12}$ 結合能を指標として内因

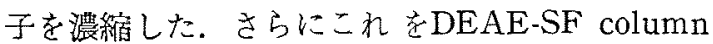
chromatographyに加，二つの蛋白のpeakを 得た(図26). 第一のpeakは小さく放射能が認めら れなかつたが，第二のpeakにはそれに相当して趃 射能が証明せられ， $B_{12}$ 結合能が認められたので， この部分を集め透析，凍結乾喿を行ない，さらに $こ れ$ CM-cellulose column chromatography

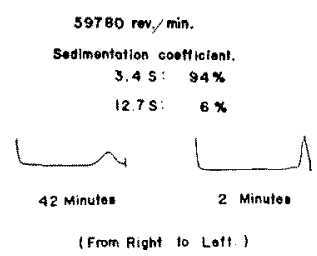

凶28. Ultracentrifuge (spinco model E).
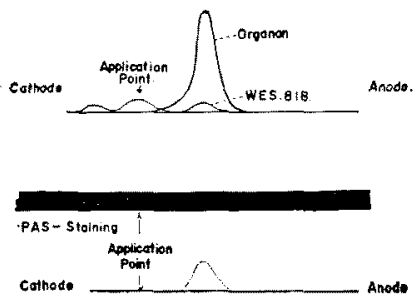

図29. Paper-electrophoregram.

によつて精製し， $\mathrm{B}_{12}$ 結合能を有する蛋白の一つ Opeakを得た（図27）。このようして10ｇの䠔 内因子濃縮物により出発して約13mgの精製物が得 られた。これを使用してB西収を譛めなかつた 胃全摘患者においてSchilling法によりその内因 于活性を检したところ，1.0mgで著明な活性を譛 めた。

なおこの精製した内因子のB 12 結合能を検した ところ，精製前の0.22 $\mathrm{g} / \mathrm{mg}$ に比し $17.4 \mu \mathrm{g} / \mathrm{mg}$ 上約80倍に上昇しているのを諗めた。

同様の方法によつてNordmark製豚内因子濃 縮物より $\mathrm{B}_{12}$ 結合蛋白を精製し，これをSpincoModel E超遠心器にて分析したところ，一つの大 きなpeak と痕跡ともいえる極动て小さなpeakが 得られた(図28). 前者のsedimentation coefficient は標淮状態に积算して $3.4 \mathrm{~S}$ ，後者のそれは 12.7 Sであつた。なお前者の大きなpeakは全蛋白量の 94\%を占めるほぐsymmetricalなpeakである.

なおOrganon製豚内因子濃肴宿物より精製した 内因子の䖍紙電気泳動図では唱一のpeakを示し, これはEllenbogen上り送られた半精製腺内因子 Wes 818の第三のpeakとも一致した。 またPA S染色による多糖類のpeak 蛋白のpeak 一一致 した（図29）。 
表 5. The composition of intrinsic factor.

\begin{tabular}{|c|c|}
\hline \multicolumn{2}{|c|}{ Protain Moiety } \\
\hline Aapartic Acid & $92^{x_{0}}$ \\
\hline Threonine & 58 \\
\hline Serine & 5.1 \\
\hline Proline & 4.8 \\
\hline Glutamio Acid & 104 \\
\hline Glyeine & 27 \\
\hline Alonine & 45 \\
\hline Voline & 4.7 \\
\hline Cyating & 0.5 \\
\hline Methionine & 1.7 \\
\hline Jooleucine & 3.7 \\
\hline Leucine & 7.5 \\
\hline Tyrosine & 3.2 \\
\hline Phenylalanine & 4.0 \\
\hline Lyoino & 5.4 \\
\hline Histidine & 2.4 \\
\hline Ammonia & 1.8 \\
\hline Argining & 3.5 \\
\hline Tryptophone & 1.6 \\
\hline Carbohydrate & moioty. \\
\hline Glucosamine & 7.7 \\
\hline Galocto samino & 3.1 \\
\hline Hexose $\left\{\begin{array}{l}\text { Golactose } \\
\text { Mannowe }\end{array}\right\}$ & 25.0 \\
\hline Fuecos & 110 \\
\hline Sioik Acid & c 0.30 \\
\hline
\end{tabular}

さらに前述のNordmark製豚内因子濃縮物を精 製したもの8.4mgをとり，日立式アミノ酸分析器 にて分析した結果, Holdsworth ${ }^{63}$ のの報告したも のとほ心゙同様の成績を得たが，多糖類の成分はや や異なるようである（表5）。

なおこのようにして得た精製内因子の分子量は 超遠心分析の結果方ら 50,000 55,000 と推定せ られ，55,000とした場合， $B_{12} と の$ 結合比はわれ われの得た精製内因子 1 分子について，0.72分子

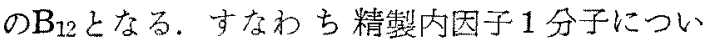
ておよそ 1 分子の $\mathrm{B}_{12}$ 唯結合するという計算にな る.

\section{VII. 補酵素型 $\mathrm{B}_{12}$ の代謝}

1958年Barkerらによつて新しいB 12 誘導体とし てcoenzyme $\mathrm{B}_{12}$ の存在が発見せられ， $\mathrm{B}_{12}$ の活性 型として注目されている64) 67).

Coenzyme $\mathrm{B}_{12}$ の生理作用については，まだ十 分明らかでない加, cobamide coenzymeを必要 とする酵素として今日，（1）glutamate isomerase, ( 2)methylmalonyl Co $\mathrm{A}$ isomerase び ( 3 ) diol をdeoxyaldehydeに転換する反応に関 与する酵素が知られている。るれわれは補醏素型

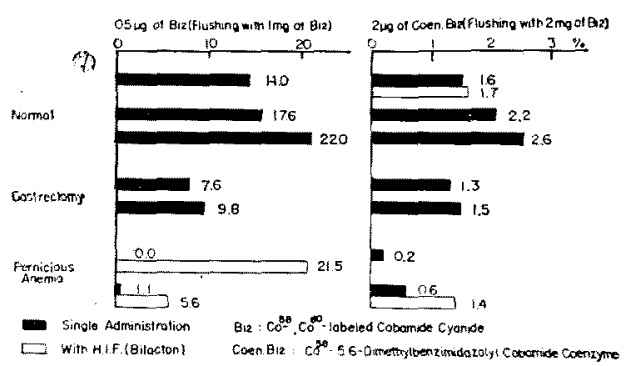

図30. Urinary excretion of orally administered

$\mathrm{B}_{12} \&$ coenzyme $\mathrm{B}_{12}$ (Schilling test).

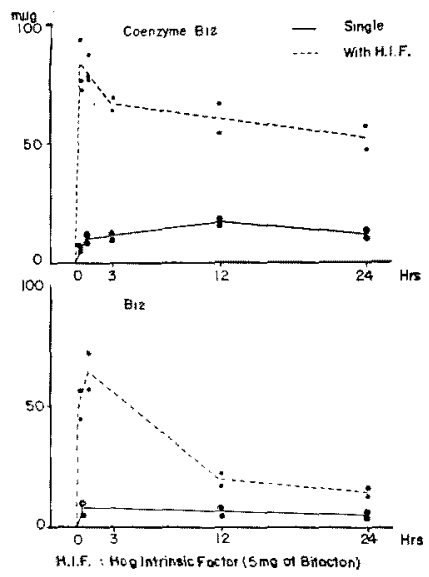

区31. Liver uptake of coenzyme $B_{12} \& B_{12}$ in rats following intravenous injection of 100 $\mathrm{m} \mu \mathrm{g}$ with and without intrinsic factor.

$\mathrm{B}_{12}$ の代謝扔よびその臨床的意義を明らかにする ために ${ }^{58} \mathrm{Co}$ あるいは ${ }^{60} \mathrm{Co} て ゙$ 標識した5,6-dimethyl benzimidazolyl cobamide coenzymeを用いて以 下の钼察を行交つた7768)697.

Coenzyme $B_{12}$ は $B_{12}$ と同様胃液と結合して非 透析性となる。滤紙電気泳動法による分析の結果 は， $\mathrm{B}_{12}$ の場合と全く同様でprimary binder㧍よ びsecondary binderに分兮れて結合する。

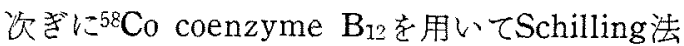
に準じてその消化管よりの吸収を検するに，胃部 分切除例で注 $\mathrm{B}_{12}$ の場合々同様, coenzyme $\mathrm{B}_{12}$ で も著しい吸收障害注認められないか，覀性貧血患 者ではcoenzyme $B_{12}$ 單独経口投与の場合には， 尿中排泄率が低く，内因子の同時投与により尿中 排浛率が正常化されることからcoenzyme $\mathrm{B}_{12}$ の 

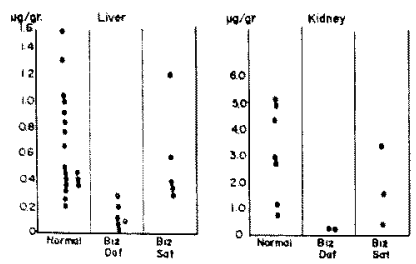

図32. Coenzyme $B_{12}$ contents in liver and kidneys $\left(B_{12}\right.$ deficiency and saturation).

場合にも消化管からの吸収は内因子依存性である ことが推定される(図30).

さらに白鼠に ${ }^{60} \mathrm{Co}$ coenzyme $\mathrm{B}_{12}$ あるいは ${ }^{60} \mathrm{Co}$ $\mathrm{B}_{12} 100 \mathrm{~m} \mu \mathrm{g}$ 青胙眽内投与し組織内分有をみ ると，單独投与後には肝藏掑 取率はcoenzyme $\mathrm{B}_{12}$ の方が富く，加つ長く持続する（図31）。内因 子の同時投与により coenzyme $\mathrm{B}_{12}, \mathrm{~B}_{12}$ と电に䀒 藏摄取率は單独投与の場合上り著しく增加方る 夰，特にcoenzyme $\mathrm{B}_{12}$ の方が $\mathrm{B}_{12}$ より長く高值 持続する。すなるち内因子の同時投与は䀒臓にお けるcoenzyme $B_{12}$ および $B_{12}$ の搑取を促進する が,とくにcoenzyme $\mathrm{B}_{12}$ の搷取の方がより著明に 促進される。この場合腎臓においてはcoenzyme $\mathrm{B}_{12}$ おひび $\mathrm{B}_{12}$ 摄取率は内因子の同時投与により， 却ってそれそれの單独投与時より低下する。

次に白鼠走用いてAbeles \& Lee ${ }^{70}$ )の方法に準 じ, 1,2-propandiol tpropion aldehydeに転換せ しめる分子内酸化還元反応を利用して，正常時，

$\mathrm{B}_{12}$ 欠元時, $\mathrm{B}_{12}$ 飽和時, $\mathrm{CCl}_{4}$ による盯障害時にお ける畈茂および腎葴のcoenzyme $B_{12}$ 量を測定し た。

$\mathrm{B}_{12}$ 欠乏白鼠では肝臓および腎䛓 のcoenzyme $\mathrm{B}_{12}$ 量は正常白鼠に比へて著明に隇少し，coenzyme $\mathrm{B}_{12}$ が $\mathrm{B}_{12}$ よりの䎐换によつて生ずることを示 唆している(図32)。 $B_{12}$ 飽和白鼠における旰臓お

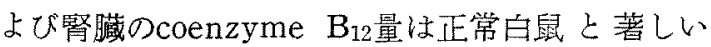
差を示さない。

$\mathrm{CCl}_{4} 1$ 回投与による急性䀒障害白鼠の旰臓では $\mathrm{CCl}_{4}$ 投与後 6 および 9 時間では零で著明に減少 するが，投与後15時間，18時間，27時間と次第 に回復する(図33). 腎臓においても䀒葴における

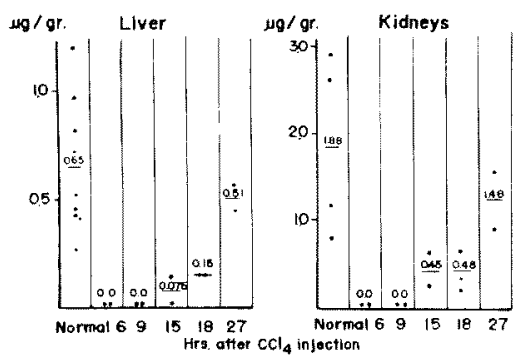

图33. Coenzyme $B_{12}$ content in liver and kidneys ( $\mathrm{CCl}_{4}$ injury).

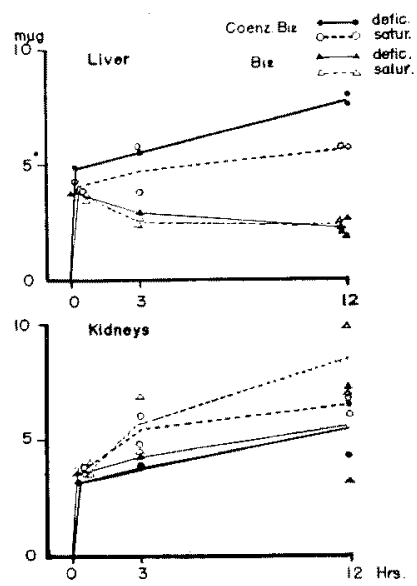

图34. Hepatic \& renal uptake of $B_{12} \&$ coenzyme $B_{12}$ following intravenous administration of $50 \mathrm{~m} \mu \mathrm{g}$ in $B_{12}$ deficient \& saturated rats.

とほ心゙同樣の変動が瑟められる。これらの成績か ら， $\mathrm{CCl}_{4}$ による旰障害時には体内における $\mathrm{B}_{12}$ よ り coenzyme $B_{12}$ 人の枟换が障害されているもの と考えられる。

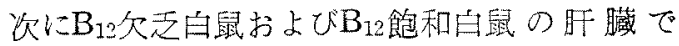

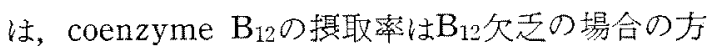
が $\mathrm{B}_{12}$ 飽和の場合より高く, 腎葴ではこの逆となつ ている(図34)。また正常， $B_{12}$ 久云， $B_{12}$ 䬷和白鼠 の各々について䀒藏抢よび腎藏のcoenzyme $\mathrm{B}_{12}$

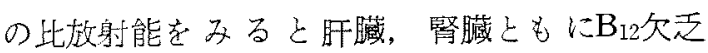
白鼠では正常白鼠より高々, coenzyme $\mathrm{B}_{12}$ の turnoverが充進していることを示している（四 35).これに反してB 12 飽和白鼠では旰臟, 留葴と 


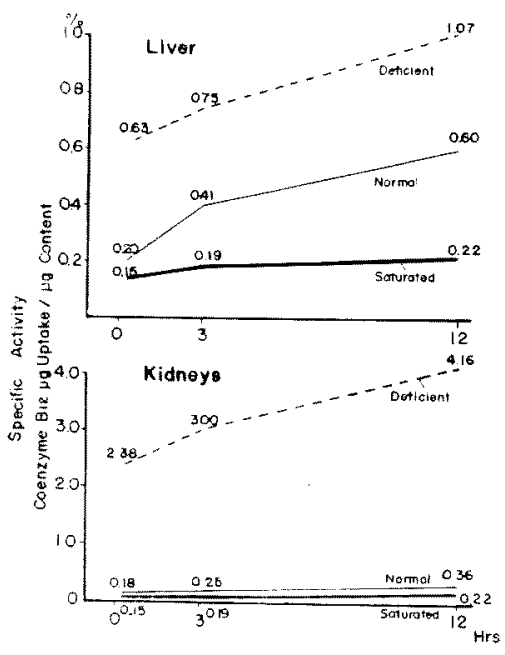

Q 35. Coenzyme $\mathbf{B}_{12}$ uptake in liver \& kidneys (normal, saturated \& deficient rats).

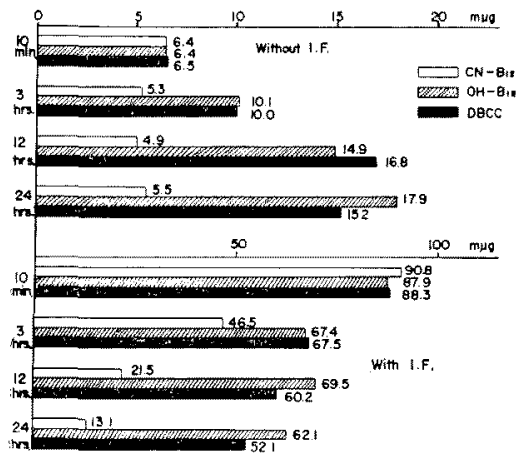

区36. Hepatic uptake of $\mathrm{CN}-\mathrm{B}_{12}, \mathrm{OH}-\mathrm{B}_{12} \&$ $\mathrm{DBCC}$ in rat following administration with or without H.I.F.

もに正常白鼠に比べてcoenzyme $\mathrm{B}_{12}$ の 比放射能 は低く，そのturnoverの低下していることを示 している. 近年hydroxocobalamin方従来の $\mathrm{B}_{12}$ (cyanocobalamin) よりも作用が持続性である

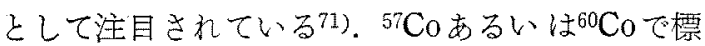
識されたcyanocobalamin, hydroxocobalamin お よびcoenzyme $\mathrm{B}_{12}$ の白鼠における肝葴提取率を 比較するとcoenzyme $\mathrm{B}_{12}$ 少最も高く, hydroxocobalaminがこれに次ぎ, cyanocobalaminは最も 低い（四36)。加 cyanocobalaminは時間と共に
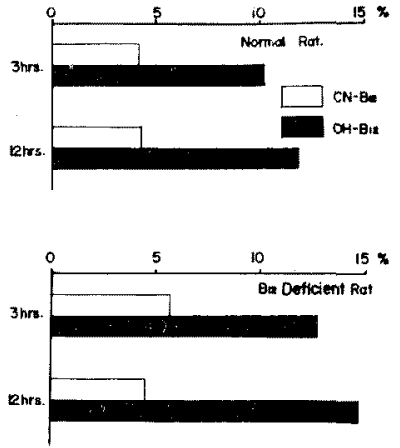

图37. Hepatic uptake of ${ }^{57} \mathrm{Co}-\mathrm{B}_{12} \quad \& \quad{ }^{57} \mathrm{Co}-\mathrm{OH}$ -

$B_{12}$ in normal and $B_{12}$ deficient rat.

肝葴掑取率が低下するが, coenzyme $\mathrm{B}_{12}$, hydroxocobalaminでは24時間まで時間と〉もに䀒摂取

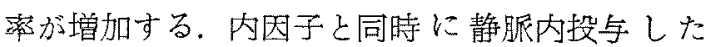
場合にはcyanocobalamin, hydroxocobalamin, coenzyme $\mathrm{B}_{12}$ と虽に肝荿摄取率は單独投与時に 比し著しく增加する。この場合䀒茞摄取率は10 分後が最高で，その後時間の経過之共にcyanocobalaminは比較的速やかに䀒藏摄取率が低下する が, hydroxocobalamin 揕取率の低下が徐々である。この傾向は B $_{12}$ 欠乏 白鼠においては一層著明である（図37）。

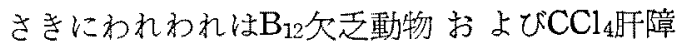
害動物における棒駼によつて， $\mathrm{B}_{12}$ が肝朦におい てcoenzyme $\mathrm{B}_{12}$ に転換されることを示唆する成 績を得たが，さらにこれを直接証明するために。 ${ }^{57} \mathrm{Co}$ あるいは ${ }^{60} \mathrm{Co}$ で標識したcyanocobalaminお よびhydroxocobalaminを白鼠あるいは人に静 脈内投与し，経時的に䀒臟組織内に標識された cyanocobalamin, hydroxocobalamin, coenzyme $\mathrm{B}_{12}$ を分别定量した，その結果，投与後72時間ま での奉駼においてcyanocobalamin, hydroxocobalaminともに時間と〉をにcoenzyme $\mathrm{B}_{12}$ に転 換される率が增加するが， hydroxocobalaminの 方がcyanocobalaminよりもcoenzyme $B_{12}$ 一の転 換率が大である(罒38).

白鼠において内因子と同時に静脈内投与した場 合にはcyanocobalamin, hydroxocobalamin $と も$ 


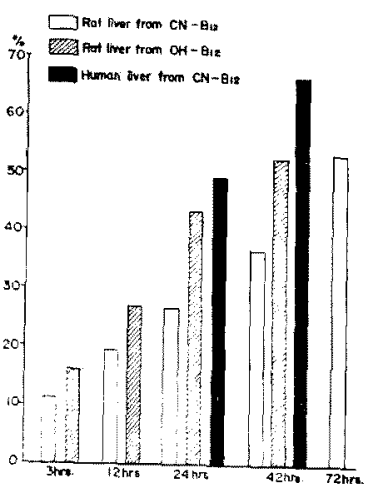

図38. Conversion rate of $\mathrm{CN} \& \mathrm{CH}-\mathrm{B}_{12}$ to $\mathrm{DBCC}$ in rat and human livers.

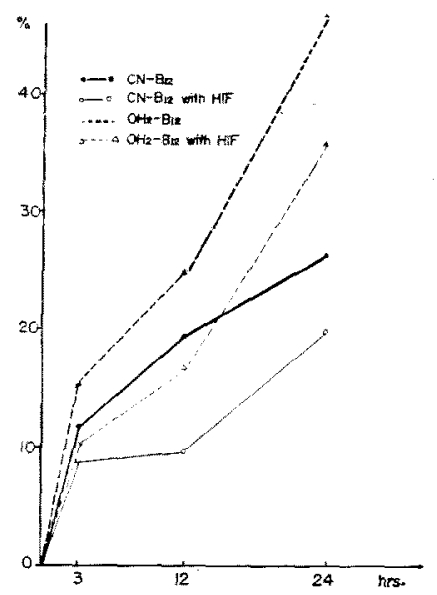

図39. Conversion rate of $\mathrm{CN}-\mathrm{B}_{12} \& \mathrm{OH}-\mathrm{B}_{12}$ to $\mathrm{DBCC}$ with or without hog intrinsic factor.

にcoenzyme $B_{12}$ への転換率は單独投与の場合よ りもや>低下するが，旰蔵への搷取率が增加する ため, coenzyme $\mathrm{B}_{12}$ に転換される絶対量は單独投 与の場合よりも大となる(図39)。またこたこの場 合に, \&ydroxocobalaminの方がcyanocobalamin よりもcoenzyme $\mathrm{B}_{12}$ への転換量が大である。な お， $\mathrm{CCl}_{4}$ にるる阶障害白鼠においてはCyanocoー balamin, hydroxocobalamin $\varepsilon \forall$ にcoenzyme $B_{12}$ 一の転換率が正常白鼠におけるよりも低值を示 すが，この場合にもhydroxocobalaminの方が cyanocobalaminに此ぺてcoenzyme $B_{12}$ への転撸 率柿大である(図40)。

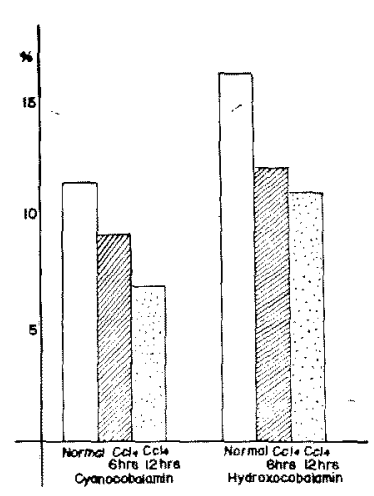

区40. Conversion rate of $\mathrm{CN}-\& \mathrm{OH}-\mathrm{B}_{12}$ to $\mathrm{DBCC}$ in normal and $\mathrm{CCl}_{4}$ injured rat liver $(3 \mathrm{hrs})$.

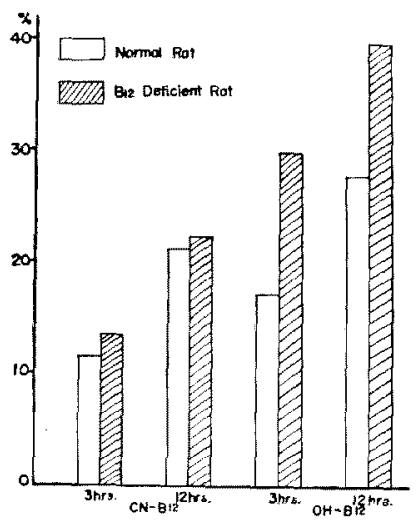

图41. Conversion rate of $\mathrm{CN}-\& \mathrm{OH}-\mathrm{B}_{12}$ to $\mathrm{co}$ enzyme $B_{12}$ in normal and $B_{12}$ deficient rat livers.

またB 12 欠乏白鼠でも旰崴におけるcoenzyme $\mathrm{B}_{12}$ への転換率はcyanocobalaminより hydroxocobalaminの方去である（図41）。

VIII. Coenzyme $B_{12}$ 欠乏時における尿中me-

\section{thylmalonic acidの排泄增加}

1960年Stadtman,その他によつて, coenzyme $B_{12}$ がmethylmalonyl-CoAのcofactor としてpropionic acidの代謝過程において てmethylmalonylCoAよりsuccinyl-CoAへの転换に関与すること が明らかにされだ2773744. ついてWhiteら75) 79)

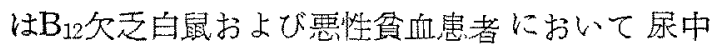
methylmalonic acidの排泄が增加し， $B_{12}$ の投与 によつてこれが正常化されることを報告した。 


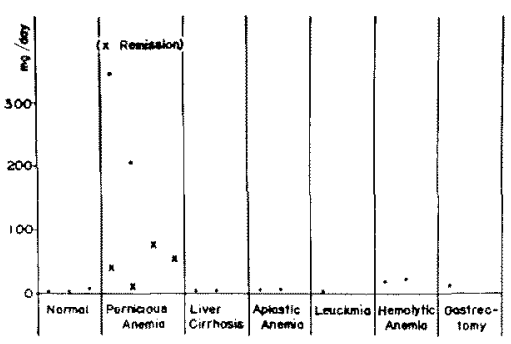

図42. Urinary methylmalonic acid excretion in various diseases.

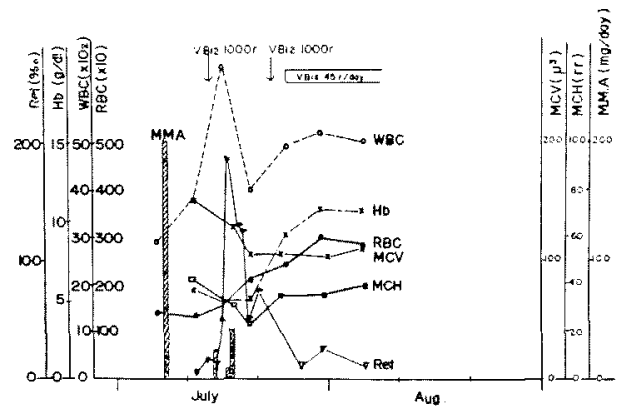

国43. Treatment of pernicious anemia and urinary excretion of methylmalonate (T.O. 43 y. female).

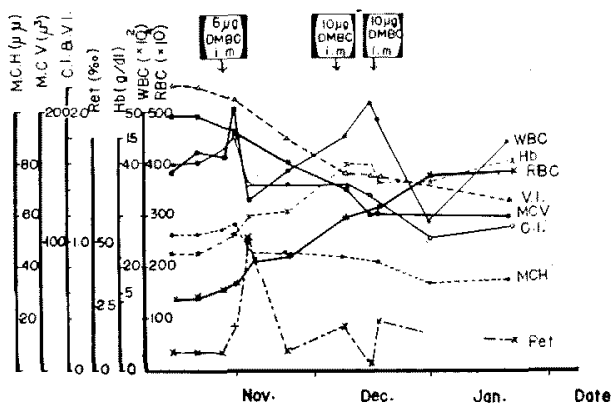

国44. Hematologic effect of coenzyme $B_{12}$ (K.K. 62 y. male. P.A. in relapse).

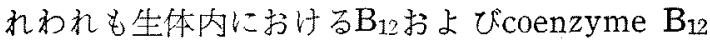
の久乏を制定する一指標として尿中methylmaio-

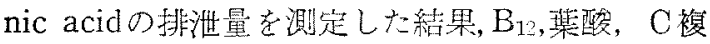
合欠乏動物では久王俍飼育開始後 $2 \sim 3$ 週間で尿 中methylmalonic acid排湘量の著明な增加を認 めた。また墨性貧血患者に扮いても治療前には， 尿中methylmalonic acidの排泄量が著明に増加 しており， B $_{12}$ よる治療徯はこれが急速に減少し
て正常值に近づくのを認めた（図42，43）。これら の成績加ら原中methylmalonic acid排泄量の 測

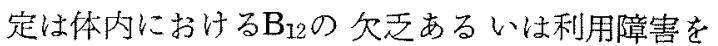
知る指標として有意戔なものと考えられる。

恶性筫血の治療にB ${ }_{12} の$ 非経口投与が必要なこ と岋いうまでもないが，われわれは䁬性貧血患者 kcoenzyme $B_{12}$ t $5 \mu \mathrm{g} 1$ 回, $10 \mu \mathrm{g} 2$ 回筋肉内注 射し, $B_{12}$ 己同様網赤血球分利, 貧血の回復, 增 大せる赤血球平均容積および色素指数ならびに右 偏したPrice-Jones氏曲線の正常復帰を諗めた（図 44). その効果注 $\mathrm{B}_{12}$ とcoenzyme $\mathrm{B}_{12}$ の分子量を考 虑に入れた場合, $\mathrm{B}_{12}$ の效果とほぶ同様であつた。

$\mathrm{B}_{12}$ のcoenzyme $\mathrm{B}_{12}$ への転換に肝臓が重要な意 義を有することは，われわれの実騃成續に上つ

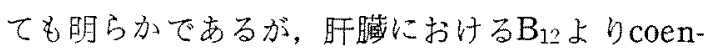
zyme $B_{12}$ への転換障害によつて巨赤芽球性貧血 をおこす場合があるか，またかっる症例にcoen一 zyme $\mathrm{B}_{12}$ の方が $\mathrm{B}_{12}$ りり治療上より有効であるか 否加今捘研究要するところである。

\section{結語}

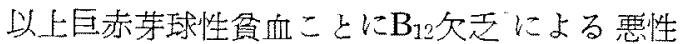
貧血および類似の巨赤芽球性貧血について，ての 病態生理，発生機序に関する知見を報告した。 Minot, Murphyらによ当盰臟食療法の発見, Castleによる外因子，内因子説の 提唱, Rickes, Smithらによる $\mathrm{B}_{12}$ の分離により巨赤芽球性督血こ とに悪性貧血の病態生理, 診断, 治療に関する研 究は著しい谁歩を逐げたが，内因子の本態，その 作用機序， $B_{12}$ 欠乏による巨赤芽球性䀜血の発生 機序，内因子久元の基盤をなす雷粘莫萎縮の発生 する原因などについては，なお解決すべき多くの 問題が残されている. 今後新しい研究方法の導入 によつてこの方面の研究が更に進展せんことを希 つてこの報告を終る。

終り炕光将るる本講演の機会を与えりれた第61回日 本内科学会総会会頭前川孫二郎教授ならびに宿題選定

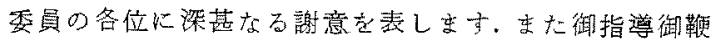
撻を賜つた恩師菜池名登教授, 井上名管教授，研究に 御援助御協力顶いた京都大学医学部内科三宅教授, 
外科木村教授，山根博士，医化学早石教授，西塚助教 授、病理学网本教授，京極明教授，工学部福井教授， 清水助教授, 食糃科学研究所岩并教授, ウ1ルス矿究 所㣟田助教授，川出助教授，国立京都病院塩田博士， 恒松博士，北野病院松浦，山本两院曼，大密博士，福 住博士, Oxford 大学 Witts 教授, ニューヨーク医科 大学 Glass 授, Merck Sharp \& Dohme: Kalman C. Mezey 博士, Squibb: David Perlman 博士, Organon: Kenneth Thompson 博士, Lederle: L. Ellenbogen 博士, Winthrop, Deutsche Nordmark の各位 ならびに日夜研究に努力世られた協同研究者各位化專 心より感謝いたします。

本研究の一部に対し，交部省科学研究費，筛原財団， Rockefeller Foundation の補助を受けたここ〉に記し て感謝の意を表する。

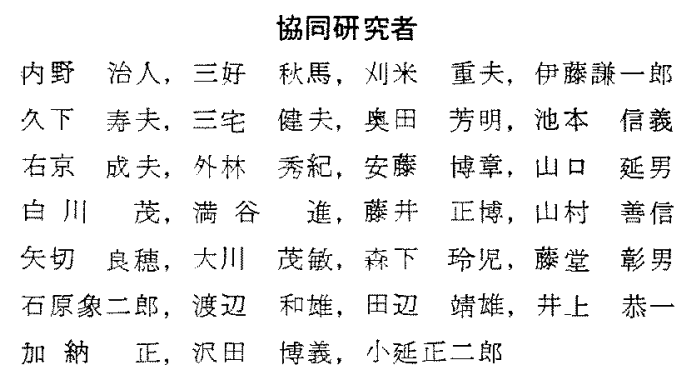

\section{文 献}

1）大塚舜一b：最新医学, 11,952, 1956. -2) 胳 坂行一, 内野治人, 右京成夫, 赤沢好温, 山本昭 吾, 安螓博章, 外林秀紀, 足立昭子: 内科, 6,212 , 昭35. -3) Minot, G.R., Murphy, W.P.: J.A. M.A., 87, 470, 1926. -4) Heinle, R.W., Welch, A.D., Scharf, V., Meacham, G.C., Prusoff, W.H.: Trans. Assn. Amer. Phycns., 65, 214, 1952. 5) Schilling, R.F.: J. Lab. clin. Med., 42, 860 , 1953. -6) Glass, G.B.J., Boyd, L.J., Gellin, G. A., Stephanson, L.: Arch. Biochem. 51, 251, 1954. 一7) 踽坂行一, 内野治人:日消誌, 60,683 , 昭38. -8) Callender, S.T., Turnbull, A., Wakisaka, G.: Brit. med. J.: (i) 10, 1954. -8) 内 野治人, 右京成夫, 脇坂行一: 最新医学, 15, 1245, 1960. -10) 脇坏行一：(日本ビタミン学会) ビタ ミン学の進歩, 第 3 集, 243 , 昭36. 一11) 脇坂行 一, 内野治人: 日本血液学全畫, $2,522,1963$. 一

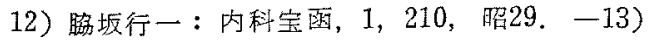
Ukyo, S.: J. Vitamin., 8, 41, 57, 81, 1962. 14) 脇坂行一, 内野治人: 内本, 5, 60, 炤35. 一 15) MacDonald, R.M., Ingelfinger, F.J., Belding, H.W.: New Engl. J. Med., 237, 887, 1947. -16)
友田正信：血液学討議会報告， $6,384,1954 .-17$ ) 有吉数：日血会誌，15，1，1952。一-18）勝圾行一, 右京成夫，池本信嶬：臨床血夜，1，13，昭35。一 19) Brodine, C. et al.: J. Lab. clin. Med., 53, 220, 1959. -20) Naish, J., Capper, W.M.: Lancet, (2), 597, 1953. -21) Witts, L.J.: Proc. roy. Soc. Med., 48, 245, 1955. -22) Badenoch, J. et al.: Brit. J. Haemat., 1, 339, 1955. -23) Girdwood, R.H.: Klin. Wschr., 36, 61, 1958. -24) 朌坂行一, 灲米重夫万: 最新医学, 15, 2852, 昭35. 一25) 璐坂行一：日本の医学の1959年（第 15 回日本医学会総会学術筮会記録)， IV, 13, 1959. -26）池本信義：内科宝囦，6,447，昭34，-27）安 滕博章：内科宝函，8,488，昭36，一-28）脇场行一, 内野治人, 池本信義, 右京成夫, 安藤博章, 外林

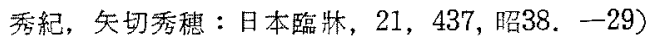
Fox, H.J., Castle, W.B.: Amer. J. med. Sci., 203, 18, 1942. -30) Landboe-Christensen, E., Plum, C.M.: Amer. J. med. Sci., 215, 17, 1948. -31) Landboe-Christensen, E., Berk, L., Castle, W.B.: Amer. J. med. Sci., 224, 1, 1952. -32) Mac Lean, L.D.: New Engl. J. Med., 257, 262, 1957. -33) Lowenstein, F.: Blood, 13, 339, 1958. -34) Badenoch, J. et al.: Brit. J. Haemat., 3, 175, 1957. -35) Girdwood, R.H.: Biochem. J., 52, 58, 1952. -36) Chanarin, L. et al.: Brit. J. Haemat., 4, 435, 1958. -37) Spray, G.H.: Proc. Nutr. Soc., 15, 119, 1956. -38) Mollin, D.L., Ross, G.I.M.: Vitamin $B_{12}$ u. Intrinsic Factor, Ferd. Enke, Stuttgart, 413, 1957. -39) Wilson, H.E., Pitney, W.R.: J. Lab. clin. Med., 45, 590, 1955. -40) Dietrich, L.S., Monson, W.J., Elvehjem, C.A.: J. biol. Chem., 199, 765, 1952. -41) Nieweg, H.O. et al.: J. Lab. clin. Med., 44, 118, 1954. -42) Narayanan, M. S. et al.: Indian. J. med. Sci., 11, 163, 1957. 43) Goldsmith, G.A.: Amer. J. Med., 680, 1958. -44）眑坂行一, 内野治人, 外林芳紀, 外林秀紀, 吉野俊昭：ビタミン，27，237，昭38，一45) 山村 善信: 近刊。一46) 赤坂清司: 日本血㴼学全書, 1 , 310. 昭38. -47) Shirakawa, S.: Jap. Arch. Int. Med., 10, 23, 1963. -48) Mauri, C.: Folia haematologica, Neue Folge, 6, 239, 1961. -49) Reisner, E.H., Jr.: Blood, 13, 313, 1958. -50)衂田 邦雄 : (日本ビタミン学会)ビタミン学の進步, 第 5 集, 123, 昭38，一51) 内野治人，筧守，山口延男：最 新学, 17，1234，昭37. - 52) Glass, G.B.J., Uchino, H.: Fed. Proc., 18, 531, 1959. -53) Glass, G.B.J., Uchino, H., Schwartz, G.: Proc. VIII. Internat. Cong. of Hematol., 2, 1159, 1962. -54）内野治人：日消誌，58，806，昭36。一-55) Keuning, F.J., Arends, A., Maudesma, E., Nie- 
weg, H.O.: J. Lab. clin. Med., 53, 127,1959. 56) Helmer, O.M., Fouts, P.J., Zerfas, L.G.: Amer. J. med. Sci., 188, 184, 1934. -57) Ellenbogen, L.: Vitamin $B_{12}$ u. Intrinsic Factor, Ferd. Enke, Stuttgart, 443, 1962. -58) Gräsbeck, R.: Advanc. clin. Chem., 3, 299, 1960. -59) Wijmegna, H.G.: Vitamin $B_{12}$ u. Intrinsic Factor, Ferd. Enke, Stuttgart, 156, 1957. -60) Kakei, M., Glass, G.B.J.: Proc. Soc. exp. Biol. VII, 270, 1962. -61) Chosy, J.J., Schilling, R.F.: J. Lab. clin. Med., 61, 907, 1963. -62) Okuda, K., Gräsbeck, R.: Proc. Soc. exp. Biol. VIII, 808, 1962. -63) Holdsworth, E.R.: Biochim. biophys. Acta (Amst), 51, 295, 1961. -64) Barker, H. A., Weissbach, H., Smyth, R.O.: Proc. nat. Acad. Sci., (Wash.) 44, 1093, 1958. -65) Barker, H.A.: Vitamin $B_{12}$ u. Intrinsic Factor, Ferd. Enke, Stuttgart, 82, 1962. -66) Gabbe, E.E., Heinrich, H.C.: Vitamin $B_{12}$ u. Intrinsic Factor, Ferd. Enke, Stuttgart, 116, 1962. -67) Coates, M.E., Doran, B.M., Harrison, G.F.: Vitamin $B_{12}$ u. Intrinsic Factor, Ferd. Enke, Stuttgart, 147, 1962. 一68) 内野治人, 右京成夫, 矢切
息䎩，脇坂行一，筧守：ビタミン，25，190, 1962. -69) Wakisaka, G., Uchino, H., Ukyo, S., Yagiri, Y.. Tomita, S.: IX. Internat. Cong. Hema* tol., Mexico City, Sept., 1962. -70) Abeles, R. H., Lee, H.A.: J. biol. Chem., 236, 2347, 1961. -71) Glass, G.B.J., Skeggs, H.R., Lee. D.H., Jones, B.L., Hardy, W.W.: Abstract of VIII Intern. Cong. Hematol., Tokyo, 253, 1960. - 72)

Stadtman, E.R., Overath, P., Eggerer, H., Lynen, F.: Biochem. biophys. Res. Commun., 2, 1, 1960. -73) Gurnani, S., Mistry, S.P., Johnson, B.C.: Biochim. biophys. Acta (Amst), 38, 187, 1960. -74) Lengyel, P., Mazumder, R., Ochoa, S.: Proc.nat. Acad. Sci., 46, 1312, 1960. -75) Arnstein, H.R.V., White, A.M.: Biochem. J., 83, 264, 1962. -76) White, A.M.: Biochem. J., 84, 41p, 1962. -77) Barness, L.A., Young, D. G., Nocho,R.: Science, 140, 76, 1963. -78) Cox, E.V.: Lancet, 853, 1962. -79) Barness, L.A., Young, D., Mellman, W.J., Kahn, S.B., Williams, W.J.: New Engl, J. Med., 268, 144, 1963. 